\title{
COSMOPOLITISMO E GLOBALIZAÇÃO: EFEITOS NA SEARA POLÍTICO-JURÍDICA CONTEMPORÂNEA*
}

\author{
Abili Lázaro Castro de Lima**
}

\begin{abstract}
RESUMO
Este artigo objetiva demonstrar que o cosmopolitismo, existente nas civilizações helenística e romana, influenciado pelo estoicismo, defendendo um mundo sem fronteiras, ensejou a apatia política dos cidadãos. No contexto contemporâneo, em face da globalização econômica, com o declínio e/ou a crise do Estado-nação, manifesta-se a também um quadro de apatia política, peculiaridade que coloca em risco a democracia e a política. Este panorama autoriza-nos a apresentar o estoicismo como um instrumento teórico para a análise e avaliação de alguns aspectos negativos da globalização no contexto político.
\end{abstract}

Sumário: 1 INTRODUÇÃO; 2 O ESTOICISMO E SUAS REPERCUSSÕES NO PLANO POLÍTICOPARTICIPATIVO; 3 O ADVENTO DE UMA NOVA PROPOSTA COSMOPOLITA: A GLOBALIZAÇÃO; 4 CONCLUSÃO; 5 REFERÊNCIAS.

\section{INTRODUÇÃO}

O objeto deste artigo é apresentar o cosmopolitismo dos estóicos, a partir da experiência das civilizações helenística e romana, como um instrumento teórico para

* O presente artigo foi concebido tendo como ponto de partida as reflexões já realizadas na dissertação de mestrado do autor intitulada: "Cosmopolitismo e Globalização: a proposta cosmopolita dos estóicos nas civilizações helenística e romana como contributo para a análise de alguns aspectos da participação política na concepção de mundo sem fronteiras presente na idéia de globalização na contemporaneidade" (UFPR/1996) e na tese de doutorado do autor, "Globalização econômica, política e direito: análise de algumas mazelas no plano político-jurídico" (UFPR/2000).

** Mestre e Doutor em Direito pela Universidade Federal do Paraná. Professor da disciplina Direito e Sociedade no curso de graduação em direito e de Sociologia do Direito no Programa de Pósgraduação em Direito da Universidade Federal do Paraná. Avaliador do INEP. Tutor do Programa de Educação Tutorial do Grupo PET-Direito da Universidade Federal do Paraná. 
auxiliar na inteligibilidade e avaliação de alguns aspectos da globalização na contemporaneidade.

A importância do objeto reside no fato de que ainda faltam referenciais teóricos e empíricos para analisar a globalização. Do ponto de vista jurídico, a importância se revela especialmente no trinômio apatia-participação-delimitação do poder político, haja vista que o afastamento do indivíduo do palco político repercute exatamente no processo de formação do direito, uma vez que o locus institucional da criação das leis é o Parlamento.

O pressuposto metodológico é que a globalização seja um indicativo de um mundo sem fronteiras.

Tentar-se-á mostrar que a globalização, ao engendrar a transnacionalização da política, enseja que as decisões políticas transcendam a esfera política do Estadonação. Este raciocínio autoriza a supor a hipótese de que o indivíduo passe a perceber que as decisões locais não têm mais tanta importância e que o centro das decisões está muito distante, sentindo que sua participação no âmbito político é cada vez mais estéril. Em um mundo sem fronteiras, talvez o cidadão não tenha outra alternativa senão assumir a condição de "consumidor", buscando cada vez mais a satisfação de suas necessidades consumistas, instigado pelo mundo que o circunda, despertando um comportamento egoísta. Tal peculiaridade parece indicar a possibilidade de se realizar um cotejo com o estoicismo.

Ao se utilizar o cosmopolitismo dos estóicos como instrumento para tornar inteligível a participação política no âmbito da globalização, não se está dizendo que a idéia dos estóicos é a mesma existente na globalização, uma vez que não possuem identidade de fundamentos históricos, empíricos e teóricos. O escopo é usar o cosmopolitismo dos estóicos como mecanismo para que se possa pensar que um mundo sem fronteiras pode gerar apatia política e, assim, colocar em risco a democracia e a política. 


\section{O ESTOICISMO E SUAS REPERCUSSÕES NO PLANO POLÍTICO- PARTICIPATIVO}

Neste item, analisar-se-á o estoicismo, cuja importância reside na influência que causou às civilizações helenística e romana, pois a Escola Estóica concebia um mundo sem fronteiras, uma cosmópolis, onde o indivíduo era cidadão do mundo, devendo desapegar-se dos laços que o ligavam ao Estado. Os seguidores desta Escola pregavam a apatia, o alheamento do mundo, que conduziu ao egoísmo. O indivíduo não se preocupava mais com os destinos da coletividade, estava preocupado com seus próprios interesses.

O objetivo, neste item, é demonstrar como a proposta cosmopolita dos estóicos contribuiu para mudar a concepção dos gregos de que a participação política deve se manifestar dentro dos limites precisos da pólis, uma vez que os estóicos preconizavam um mundo sem fronteiras. Mostrar-se-á, ainda, que esta modificação ensejou a apatia política dos indivíduos, comportamento que foi extremamente favorável para controlar os povos conquistados por aquelas civilizações. No âmbito jurídico, verifica-se que não haverá mais a atuação dos indivíduos na votação das leis, como resultado da atuação dos governos despóticos na civilização helenística e no período imperial da civilização romana. Além disso, segundo as teorizações da Escola, uma vez implantado o Estado único, as leis seriam prescindíveis. ${ }^{1}$

\subsection{A CIVILIZAÇÃO HELENÍSTICA: DA PÓLIS À COSMÓPOLIS}

Em que pese a civilização grega ter sido o palco de muitas conquistas grandiosas em vários campos do conhecimento, seu declínio consolidou-se com as invasões de Felipe II da Macedônia, entre 359 a 336 a.C.

Com a morte de Felipe, sucedeu-lhe o seu filho Alexandre Magno, o qual foi

\footnotetext{
${ }^{1}$ NADER, Paulo. Filosofia do direito. 2. ed. Rio de Janeiro: Forense, 1992, p. 113.
} 
educado por Aristóteles. Alexandre era um grande admirador da cultura grega, tendo-a difundido no seu império, através de suas conquistas militares. Por sua vez, a cultura dos povos conquistados acaba influenciando a cultura grega.

Desta interação cultural surge a cultura helenística. "É o fenômeno do helenismo, isto é, a universalização da língua e da cultura gregas, de sua expansão pelos países orientais (Ásia Menor, Egito, Pérsia) que os exércitos de Alexandre tinham aberto à influência espiritual da Grécia. E Atenas já não é o único centro deste mundo intelectual; formam-se outros focos de cultura: Pérgamo, Antióquia e, principalmente, Alexandria, no Egito". ${ }^{2}$

Não obstante a cisão das duas culturas (helênica e helenística), pode-se constatar que, mesmo com algumas diferenças, houve certa continuidade da civilização helênica. O grego continua a ser utilizado pelas classes cultas e por certos segmentos da população, a ciência e a lógica grega continuam a influenciar fortemente a civilização helenística. Porém, no plano político, a democracia é sobrepujada pelo despotismo extremamente rigoroso, ${ }^{3}$ sendo que algumas cidades-estados gregas persistiram, tendo outras sucumbido, nas quais foi adotada a monarquia. ${ }^{4}$

Tendo a pólis sucumbido, ${ }^{5}$ com ela morre o cidadão. ${ }^{6}$ Agora, todos os homens

${ }^{2}$ MONDIN, Battista. Curso de filosofia. 7. ed. São Paulo: Paulus, 1982, v. 1, p. 109.

${ }^{3}$ (SCHILLING, Kurt, na sua História das idéias sociais. Rio de Janeiro: Zahar, 1966, p. 101-102), destacava que o objetivo das teorizações de Platão e Aristóteles foi tentar elidir a decadência da pólis. Aduz que fracassaram, como se constata no final da Idade Antiga, cujas novas idéias sociais conformam-se com este declínio (sobretudo o epicurismo e o estoicismo, conforme veremos mais tarde). Assevera ainda que: "Para compreender essas novas idéias sociais é preciso observarmos rapidamente o Estado no fim da Antigüidade. Trata-se de uma monarquia desenvolvida inicialmente no império de Alexandre, a partir da realeza macedônica meio bárbara, que era uma realeza de tribo; depois, nos sucessivos Estados helenísticos, orientando-se cada vez mais para as formas de despotismo oriental, renovando-as; enfim, devorando tudo no cesarismo romano que se desenvolvera a partir da ditadura de Sila, do principado de Pompeu à monarquia de César, mas que se torna a partir de então um curioso despotismo oriental, renovado e retocado pela razão grega e o Direito Romano". Acerca do ocaso da pólis, consultar também o estudo realizado por George H. SABINE (História de la teoria política. México: Fondo de Cultura Economica, 1945, p. 127-135).

${ }^{4}$ BURNS, Edward McNall. História da civilização ocidental. 31. ed. Rio de Janeiro: Globo, 1989, v. 1, p. 125.

${ }^{5} \mathrm{O}$ panorama da civilização helenística foi muito bem sintetizado por Guido FASSÒ, em (Historia de la filosofía del derecho. 3. ed. Madrid: Pirâmide, 1982, v. 1, p. 74): "Após a conquista macedônica da Grécia e do Oriente, e a posterior formação de um Estado que compreendia todo o 


\author{
igualam-se na condição de súditos, pertencentes não a uma pólis, mas a uma \\ "cosmópolis", 7 ou seja, a cidade universal. ${ }^{8}$
}

Giovanni Reale e Dario Antiseri tratam desta questão:

\begin{abstract}
De 'cidadão', no sentido clássico do termo, o homem grego torna-se 'súdito'. A vida nos novos Estados se desenvolve independentemente do seu querer. As novas 'habilidades' que contam não são mais as antigas 'virtudes civis', mas são determinados conhecimentos técnicos que não podem ser do domínio de todos, porque requerem estudos e disposições especiais. Em todo caso, estas perdem o antigo conteúdo ético para adquirir um conteúdo propriamente profissional. $\mathrm{O}$ administrador da coisa pública torna-se funcionário, soldado ou mercenário. E, ao lado deles, nasce aquele homem que, não sendo mais nem o antigo cidadão nem o novo técnico, assume diante do Estado uma atitude de desinteresse neutro, quando não de aversão. As novas filosofias teorizam essa nova realidade, colocando o Estado e a política entre as coisas neutras, ou seja, moralmente indiferentes ou francamente entre as coisas a evitar.

Em 146 a.C., a Grécia perde totalmente a liberdade, tornando-se uma província romana. O que Alexandre sonhou, os romanos o realizaram de outra forma. E assim o pensamento grego, não vendo uma alternativa positiva à Pólis, refugiou-se no ideal do 'cosmopolitismo', considerando o mundo inteiro uma cidade, a ponto de incluir nessa cosmópolis não só os homens mas também os deuses. Desse modo, dissolve-se a antiga equação entre homem e cidadão e o homem é obrigado a buscar nova identidade. ${ }^{9}$
\end{abstract}

mundo de então, Estado que Alexandre deliberadamente havia criado como um intento de realização de uma comunidade universal, as relações entre indivíduo e Estado, tal como se haviam desenvolvido na pólis e teorizado pelos pensadores crescidos nela e educados em seu ideal, haviam perdido todo fundamento e significado. Na monarquia universal de Alexandre - cujo ideal sobreviveu na mesma luta entre seus sucessores, e mais tarde em escassa medida realizado e perpetuado no império de Roma -, ainda que as velhas instituições da pólis formalmente subsistiram, não tiveram outra função e outro significado que as de serem órgãos da Administração local".

${ }^{6}$ Esta constatação foi observada por Guido FASSÒ (op. cit., p. 74): "A participação integral do indivíduo na vida do Estado havia, pois, diminuído. Num Estado-universo (Estado universal), como o de Alexandre, e, mais tarde, no romano, o indivíduo não podia seguir considerando a política como ética, como expressão total da própria personalidade: ou se alijava dela, encerrando-se numa moral individualista dominada pelos problemas do homem como indivíduo, não como cidadão; ou bem se sentia cidadão, sim, porém do mundo: não, pois, polites, senão cosmopolites. Em ambos os casos, o vínculo clássico entre ética e política havia sido quebrado".

${ }^{7}$ VALVERDE, José Maria et allii. História do pensamento. São Paulo: Nova Cultural, 1987, v. 1, p. 102.

${ }^{8}$ Conforme José Maria VALVERDE et allii (op. cit., p. 116): "O ideal cosmopolita traduzse no estoicismo por idéias de humanidade (humanistas, em latim) e de ecumenismo (palavra que deriva de cecumenicu, ou terra de todos). Tais idéias associam-se à idéia estóica de que o mundo é o logos, de tal modo que suas partes encontram-se unidas entre si e com o todo numa relação bem precisa: a simpatia".

${ }^{9}$ REALE, Giovanni; ANTISERI, Dario. História da filosofia. 2. ed. São Paulo: Paulinas, 1990, v. 1, p. 228. 
Tal entendimento esvaziava totalmente a noção de cidadania, posto que esta condição era franqueada a todos, independentemente da sua participação ou não na administração do Estado. ${ }^{10}$

Adicionando-se tal fato com o despotismo estatal, conclui-se que a vida política torna-se um assunto alheio e desinteressante à grande parcela da população. ${ }^{11}$

Ante à impossibilidade de desenvolver-se no âmbito político, o homem voltase para si mesmo: "O que importa agora é a intimidade do homem, a sua vida privada, buscar para ela regras de conduta pelas quais as pessoas possam viver bem e em qualquer tempo e circunstância". ${ }^{12}$

Nesse sentido, assevera Kurt Schilling: "A razão pela qual, no helenismo e no Império Romano, o homem tinha necessidade da Filosofia como de uma medicina mentis era que ele perdera os objetivos de sua existência na ocupação ditatorial do governo, afastava-se, desiludido, da pólis e procurava um guia que lhe pudesse ensinar

${ }^{10}$ Segundo José Maria VALVERDE et allii (op. cit., p. 102-103): "Mas entender assim a noção de humanidade a todos os homens, sem distinção, significa também torná-la vazia e abstrata. Antes, na pólis, ser homem indicava uma situação e uma condição bem precisas: participar da vida pública e decidir os destinos da comunidade. Sob o império, porém, homens livres e escravos equivalem-se (todos são homens); mais do que isso, não há mais possibilidade de influir na vida política, que se torna um assunto alheio à maioria das pessoas. $\mathrm{O}$ homem não é mais essencialmente um homem político". [...] "A Filosofia do período helenístico volta-se então para a vida interior do homem - de qualquer homem -, pois a sua realização na vida exterior como animal político está interditada. O que importa agora é a intimidade do homem, a sua vida privada, buscar para ela regras de conduta pelas quais as pessoas possam viver bem, em qualquer tempo e circunstância. De certo modo, esse tipo de pensamento corresponde ao significado popular de "filosofia": um receituário da "arte de viver" ou, como se diz, "filosofia de vida".

11 No tocante à participação política no âmbito da civilização helenística, leciona Kurt SCHILLING (op. cit., p. 102-103): "Apesar disso, o império não era como tinham sido a pólis ou mesmo os antigos despotismos orientais, uma verdadeira comunidade. Tratava-se de uma unidade econômica e administrativa, a unidade de uma soberania militar, na qual uma multidão de súditos viviam uns ao lado dos outros. Esses súditos não participavam do governo e não eram mais, como no Oriente Antigo, representados pelo rei ou o imperador. As formas de representação não passavam de aparência, propaganda e hipocrisia. Era assim que todo o mundo e cada um por si podia ocupar-se com seus interesses econômicos, culturais ou religiosos, mas sobretudo entregar-se aos prazeres da vida sob todas as suas formas. O aparelho político do soberano garantia a paz por meio de uma polícia remunerada e de soldados profissionais (e isso já no próprio interesse do soberano). Por esse motivo é que o rei ou o imperador era realmente o soter, o salvador, como é sempre chamado nas efígies das moedas ou nas inscrições. Era ele que salvava seus súditos da miséria, da insegurança das guerras civis e das inúteis lutas de partidos, mesmo quando governava rigorosamente, quando os coletores de impostos trabalhavam não somente para ele, mas também para si próprios e pilhavam as províncias".

${ }^{12}$ VALVERDE, op. cit., p. 103. 
Como conseqüência do comportamento passivo dos indivíduos, estes deixavam de serem cidadãos para tornarem-se súditos e os excessos de individualismo ${ }^{14}$ geravam o egoísmo, rompendo os elos entre a ética e a política, que Aristóteles havia brilhantemente teorizado. ${ }^{15}$

Nesse diapasão, lecionam ainda Reale e Antiseri que:

A ética clássica, até Aristóteles, era baseada no pressuposto da identidade entre homem e cidadão; por isso, era baseada na política e até subordinada a ela. Pela primeira vez na história da filosofia moral, na época helenística, graças à descoberta do indivíduo, a ética se estrutura de maneira autônoma, baseando-se no homem como tal, na sua singularidade. As tentações e as concessões egoísticas que assinalamos são precisamente a exasperação desta descoberta. ${ }^{16}$

A cultura helenística gerou três escolas filosóficas: o epicurismo, ${ }^{17}$ o

13 SCHILLING, op. cit., p. 104.

14 Neste particular, aduz George H. SABINE (op. cit., p. 147): "Assim, pois, o pensamento político teve que aclarar duas idéias e mesclá-las num esquema de valores comum: a idéia de indivíduo, exemplar distinto da espécie humana que tinha uma vida puramente pessoal e privada, e a idéia de universalidade, de uma humanidade que alcançava a todo o mundo e no qual todos os homens estavam dotados de uma natureza comum. Isto era um suposto que havia desempenhado um papel pouco importante na ética da cidade-estado na qual o indivíduo aparecia como cidadão e sua maior significação se baseava no seu_status ou sua função. No mundo grande poderia dizer-se que um indivíduo tivera alguma função que realizar - salvo em algum sentido religioso -, porém podia, por assim dizer, converter na virtude sua própria insignificância. Poderia proclamar que sua vida íntima, impossível de ser compartilhada por outra pessoa, era a origem de todos os demais valores. Em outras palavras, poderia reclamar um direito inerente, o direito a que se respeitasse sua própria personalidade. Porém isto exigia, por sua vez, um correspondente aumento de sentido ético à idéia de universalidade. À mera semelhança de espécie havia que acrescer a semelhança de espírito, a homonoia ou concórdia, uma união de corações que faz da espécie humana uma família comum ou fraternidade".

${ }^{15}$ Aduz Guido FASSÒ (op. cit., p. 74), que: "Este mundo helenístico, não contido já nos estritos limites do Estado-cidade, e aberto, pelo contrário, aos influxos das civilizações daqueles povos que os gregos dos séculos precedentes haviam considerado sempre como inferiores, 'bárbaros', e que agora se consideravam como iguais, como cidadãos de uma única e imensa cidade, apresenta também, no campo filosófico, caracteres muito distintos do mundo helênico que teve por centro Atenas. $\mathrm{O}$ interesse especulativo enfraquece; não se encontram pensadores de relevo nem grandes sistemas filosóficos; é escasso o interesse pela metafísica, e a moral tende essencialmente a traçar ideais de vida quieta e auto-suficiente alijada de qualquer compromisso ativo na sociedade e no Estado".

${ }^{16}$ REALE; ANTISERI, op. cit., p. 229.

17 Segundo Battista MONDIN (História da filosofia, v. 1, p. 113-115) "O Epicurismo, fundado por Epicuro de Samos (falecido por volta de 260 a.C.), é uma filosofia que, em muitos 
ceticismo (cinismo) ${ }^{18}$ e o estoicismo.

Passar-se-á a desenvolver a análise do estoicismo, eis que o seu estudo possibilitará compreender melhor a temática da participação política, no que se refere à apatia que engendrou, peculiaridade que iria influenciar as civilizações helenística e romana.

\subsubsection{A Escola Estóica}

A escola estóica foi fundada por Zenão de Cítio (333/332-262 a.C.), de origem fenícia, cujo nome lhe é atribuído posto que ensinava sob os pórticos (stoá) em Atenas.

\section{Conforme as lições de Paulo Nader:}

O estoicismo é uma doutrina que teve os seus antecedentes com a Escola Cínica, sobretudo no pensamento de seus corifeus Antístenes (445-370 a.C.) e Diógenes (413-323 a.C.). Para eles, os homens deveriam limitar as suas necessidades e depender menos das coisas. Cada cidadão deveria agir livremente e desatar os laços que o prendiam ao Estado e se transformar

aspectos, se contrapõe ao estoicismo. Como filosofia , ela é essencialmente materialista (identifica os princípios primeiros das coisas com os átomos e com o vazio, mecanicista (todos os fenômenos se reduzem ao movimento e à estas leis), sensista (o único conhecimento verdadeiro é o dos sentidos) e hedonista (a felicidade consiste no prazer)". [...] "O prazer no qual, para Epicuro, consiste a felicidade é a vida pacífica, a paz da alma (tranquillitas animi, tranqüilidade da alma), a ausência de qualquer preocupação: a "ataraxia" (ataraksía). O prazer é entendido, portanto, como ausência de dor e não como satisfação de paixões. A virtude é o meio para se conseguir o verdadeiro prazer. Virtuoso é aquele que aproveita todo o deleite com moderação e medida e que limita o seu desejo àqueles prazeres que não perturbam a alma. Para a completa consecução da paz da alma, da ataraxia, da felicidade, Epicuro recomenda libertar-se de três preocupações: dos deuses, da morte e da atividade política."

${ }^{18}$ Assevera Umberto PADOVANI e Luís CASTAGNOLA na obra (História da filosofia. 15. ed. São Paulo: Melhoramentos, 1990, p. 166) que: "Mais coerente do que as escola precedentes, especialmente do que o estoicismo, com os fins práticos de uma filosofia de renúncia, é o ceticismo. Visa alcançar a paz almejada negando não apenas a ação, mas também o pensamento que implica na pesquisa, na escolha, na responsabilidade, na perturbação. O ceticismo clássico começa com Pirro de Elis (362-275 a. C.); encarna-se, a seguir, na média acadêmica com Carnéades; e, enfim, ressurge na forma pirroneana com Sexto Empírico, a princípios da era vulgar. O ceticismo tenta demolir criticamente o conhecimento sensível, bem como o conhecimento intelectual e o da opinião". 
em cidadão do mundo (cosmopolita). A atenção dos homens deveria voltar-se para as leis da virtude e não para os costumes e leis impostos pelo Estado. Pregaram o retorno ao primitivo estado de natureza. ${ }^{19}$

\section{A doutrina da Escola Estóica ${ }^{20}$ foi sistematizada por Crisipo (281-208 a.C.),} expandindo-se pela Grécia e inclusive em Roma, como se verá no próximo item.

Os estóicos asseveravam que o universo era regido por um princípio geral, denominado $\operatorname{Logos},{ }^{21}$ ou seja, a razão. O homem e todas as coisas que haviam no mundo estavam subordinados a este princípio, cuja essência era a racionalidade ("segundo a natureza racional do homem"22). "O motivo que os levou a admitir a razão (Logos) como elemento primordial do cosmo é o fato de que o homem é dotado de razão. Ora, o homem é manifestação do cosmo, e como o todo não pode ser menos perfeito que as suas partes, não se pode aceitar que o cosmo seja destituído de razão". ${ }^{23}$

O homem que vive consoante à razão é aquele que se afasta das paixões, que

${ }^{19}$ NADER, op. cit., p. 112.

${ }^{20}$ Para um maior aprofundamento do estoicismo, são importantes os estudos de Bertrand RUSSEL, na obra (História da filosofia ocidental. São Paulo: Nacional, 1957. l. 1, p. 293-313).

${ }^{21}$ O Logos foi definido com precisão por Guido FASSÒ (op. cit., p. 77): "Segundo os estóicos, o universo está animado por um princípio absoluto, que é o logos, razão: e esta Razão universal é a que, como já havia dito Heráclito, invade e move a matéria identificando-se com ela. A visão estóica da realidade é, em suma, decididamente panteísta: a divindade é concebida como imanente ao mundo: Deus é o princípio animador do universo, do que é sua causa intrínseca, a lei. E esta lei é razão, a mesma razão que é essência da alma humana. É evidente que, quando a propósito do estoicismo, se fala de uma lei reguladora do cosmos, a palavra lei vem a assumir um significado complexo. A lei de que nos falam os estóicos é a necessidade universal da natureza - natureza que compreende também ao homem: norma da mesma, porém norma que é intrínseca, que expressa ao mesmo tempo dever ser e o ser, os que, por enquanto, coincidem. E, com efeito, desta identificação que comportava o panteísmo estóico, da normatividade - característica essencial da lei - com a necessidade física, se deriva para as proposições que dão a esta última o nome de 'lei'". E complementa Kurt Schilling, op. cit., p. 114: "Partindo da hierarquia da natureza, , na qual cada existência tem seu próprio lugar, sua vocação e sua finalidade, vê-se surgir uma quantidade de deveres mais ou menos longínquos, um direito natural para o uso do homem. Esse direito é tanto um dever - o que é exigido no officium, o cargo, o posto em que se é colocado (como em Platão) - quanto um direito à participação, livremente consentida pela vontade, na ordem do Universo. [...] É, antes de tudo, a verdade que nasce do conhecimento racional da ordem do mundo. Esse direito chama-se então, segundo o termo estóico, conservado até nossos dias, 'direito natural', em oposição a todo direito outorgado, decidido, convencionado ou imposto. Em termos modernos, é o direito ‘positivo’".

\footnotetext{
${ }^{22}$ MONDIN (op. cit., p. 111).

${ }^{23}$ Ibid., p. 110.
} 
têm apenas o condão de perturbá-la. Uma vez que o mundo, sendo regido pela razão, impõe que todos se reconheçam como parte dela e aceitem impassivelmente, ou seja, sem paixão, a sua condição. Neste contexto, a liberdade consiste na ausência de paixões. "Nisto consiste a liberdade, e é por isso que o homem pode ser livre, mesmo sendo escravo. Ausência de paixão: apatia - esse é o ideal ético dos estóicos. Assim, o homem é livre na medida em que se conforma com às leis do logos". ${ }^{24}$

Aristóteles compreendia a felicidade como um fim e a virtude como um meio, e que elas só se concretizariam na medida em que o cidadão participasse da vida pública e nos destinos da comunidade. ${ }^{25}$

Os estóicos, ao contrário, as identificaram:

\begin{abstract}
A felicidade, para eles, consiste em viver segundo a razão (segundo o Logos) ou, o que dá no mesmo, em viver segundo a natureza (segundo a natureza racional do homem); por outro lado, viver segundo a razão equivale, para os estóicos, a ser virtuoso.

Mas, que vem a ser virtude? Ela é uma disposição interna pela qual a alma está em harmonia consigo mesma, isto é, com o próprio Logos. A virtude não consiste, como pensava Aristóteles, no justo meio entre dois vícios opostos, mas em um dos dois extremos: no extremo que é conforme à razão (o outro extremo é conforme as paixões). Entre virtude e vício não há meio-termo; ninguém é mais ou menos viciado ou virtuoso: é simplesmente virtuoso ou viciado. [...]
\end{abstract}

A prática da virtude, segundo os estóicos, consiste na apatia (apátheia), isto é, a anulação das paixões e na superação da própria personalidade. ${ }^{26}$

\footnotetext{
${ }^{24}$ VALVERDE, op. cit., p. 110.
}

${ }^{25}$ Carl J. FRIEDRICH, na obra (Perspectiva histórica da filosofia do direito. Rio de Janeiro: Zahar, 1965, p. 44-45), sintetiza as repercussões decorrentes do advento do pensamento estóico em relação à pólis e às teorizações de Aristóteles no que tange à participação política: "O que é decisivo para a Filosofia do Direito é, acima de tudo, fixarmos que os estóicos fizeram explodir a estrutura da pólis, que para Platão e Aristóteles fora algo indiscutível, e proclamaram a humanidade como uma comunidade universal. Um deus, um Estado, uma lei - esta bem conhecida fórmula estabelece a doutrina dos estóicos de um modo bastante simples e claro. Um homem é diferente de outro homem não pelo fato de pertencer a uma pólis, mas unicamente por ser um homem sábio, que reconhece a doutrina estóica, ou um tolo, que não a reconhece. Por essa razão, a verdadeira pólis não é qualquer pólis existente, como Atenas, mas, de fato, uma comunidade de todos esses homens sábios. Todos estão sujeitos a um Deus e a uma lei (lex). No Digest (I. 3. 2.), o grande Crisipo, que articulou a doutrina estóica num sistema, é exaltado como um filósofo de estóica sabedoria e dele se diz ter confirmado, em seu trabalho sobre nomos: 'O nomos [lei básica] governa todas as coisas divinas e humanas ...'".

$$
{ }^{26} \text { MONDIN, op. cit., p. 111-112. }
$$


A Escola Estóica preconizava a fundação de um Estado universal, tendo como alicerce a igualdade, inexistindo distinções de classes ou de fronteira. ${ }^{27}$

Aduz George H. Sabine, nesse sentido, que: "No estado ideal, dizia, os homens viveriam como um só 'rebanho', sem família, e é de se presumir que sem propriedade, sem distinção de raça nem classe e sem necessidade de dinheiro nem tribunais de justiça". ${ }^{28}$

As conseqüências da implantação no Estado universal (cosmópolis), no âmbito do direito, foram enunciadas por Paulo Nader, a partir das teorizações de Zenão de Cítio: "Pelos princípios gerais do estoicismo se depreende a existência de um Direito Natural, que seria aquele em total harmonia com a razão que governa universo. Com a implantação do Estado único, o Direito Natural tenderia a se efetivar espontaneamente, prescindindo de leis, pois estas não seriam mais necessárias, conforme o pensamento do fundador da Escola". 29

A característica cosmopolita dos estóicos foi ressaltada por Vitorino Félix Sanson: "Os estóicos pregam a fraternidade universal, a igualdade humana, o cosmopolitismo, condenam a escravidão. Esta doutrina é conseqüência lógica dos princípios cosmológicos, e também uma tomada de posição política histórica, contra a visão estreita da polis grega, e favorável à posição macedônica dos grandes impérios, que abarcam terras e povos das mais diversas culturas". ${ }^{30}$

Kurt Schilling também analisou esta característica cosmopolita ao aduzir:

Outrora, na antiga pólis, a comunidade baseava-se no connubium e no commercium, e

${ }^{27}$ Tais concepções do pensamento estóico foram assim comentadas por George H. SABINE (op. cit., p. 153-154): "Para tanto, existe um estado universal. Tanto os deuses como os homens são cidadãos dele, e têm uma constituição - a reta razão - que ensina os homens o que se deve fazer e o que se deve evitar. A reta razão é a lei da natureza, a protetora universal do justo e do bom, imutável enquanto aos seus princípios e obrigatória a todos homens, tanto governantes como governados - a lei de Deus".

${ }^{28}$ SABINE, op. cit., p. 149.

${ }^{29}$ NADER, op. cit., p. 113.

${ }^{30}$ SANSON, Vitorino Félix. Estoicismo e cristianismo. Caxias do Sul: EDUCS, 1988, p. 23. 
tornara-se consciente por meio do mito e do culto. Era sempre comunidade de um grupo determinado: a família, a parentela, a tribo, a aldeia, a cidade o povo. Agora a comunidade se baseia numa simpatia intelectual como o cosmos, único valor da vida que subsiste ainda quando se venceram as paixões. Ela é não somente a comunidade de todos os homens (povos, indivíduos, da mesma língua e da mesma raça), mas também de todos os seres vivos e de todas as coisas do mundo. De fato, o próprio mundo, com todos os seres e todas as coisas, é concebido como a mais sábia existência. A dependência de um grupo social determinado: família, cidade, comunidade de língua ou de educação, ou de uma raça ou classe, é caracterizada como um simples 'acaso do nascimento'. O cidadão torna-se, em um sentido imediato (do modo inteiramente diverso do que se usa e abusa atualmente), 'cidadão do mundo', colocado em seu lugar no cosmo vivo. A palavra que a isso se refere: 'cosmopolita', cidadão do cosmos, como se dizia antes do cidadão de Atenas, de Roma, etc., foi retomada de Antístenes pelo estoicismo e se encontra já em Demócrito sob formas variadas. Contudo, foi só no estoicismo que adquiriu seu sentido e seu valor universal. ${ }^{31}$

\section{O estoicismo, na medida em que procurava diminuir a diferença existente}

entre os indivíduos, também o fazia em relação aos Estados, colimando a concretização do Estado Universal, quando propugnava um sistema jurídico de âmbito mundial. George H. Sabine apresenta tais concepções:

Se o estoicismo diminui a importância das distinções sociais entre os indivíduos, tendeu também a promover a harmonia entre os estados. Há sempre duas leis para todo homem, a lei de sua cidade e a lei da cidade universal, a lei do costume e a lei da razão. É a segunda que deve ter autoridade superior e a que deve contribuir à regra a que devem conformar-se às leis e costumes das cidades. Os costumes são diversos e múltiplos, porém a razão é una, e atrás da variedade de costumes deve haver alguma unidade de fim. O estoicismo tendia a conceber um sistema jurídico de âmbito mundial, composto por infinitos ramos locais. As diferentes localidades poderiam diferir segundo as circunstâncias, sem deixar isso de ser razoáveis, tanto que a racionalidade de todo o sistema tendia a impedir que as variações se convertessem em oposição. Em substância, isso não difere muito da harmonia 'ou união de corações’ por que fazia votos Alexandre. No mundo helenístico havia por todas as partes cidades e outras autoridades locais dotadas de maior ou menor autonomia. As monarquias as mantiveram unidas mediante um direito comum ou real. A arbitragem chegou a ser uma prática reconhecida e muito difundida de resolver conflitos entre as cidades. No regime interno o juízo dos pleitos privados ante comissões judiciais procedentes de outras cidades mudou em grande parte os antigos júris populares. ${ }^{32}$

Apesar de haver restado apenas fragmentos dos textos de Zenão de Cítio, o mesmo asseverava em "Do Estado": "'Não deveríamos viver em Estados ou

\footnotetext{
31 SCHILLING, op. cit., p. 115-116.

32 SABINE, op. cit., p. 154.
} 
populações divididas e cada um com seu direito, mas crer que todos os homens são nossos compatriotas e concidadãos; não deveria haver mais do que uma forma de vida e uma ordem estatal, do mesmo modo que um rebanho comum se cria segundo uma só lei'".33

Esta pretensão era extremamente útil aos anseios expansionistas da civilização helenística, uma vez que induzia os povos conquistados à inexistência de discriminação no tocante à sua origem, como uma forma de aplacar quaisquer tentativas de insurreição. Isso também reforçava a idéia da cosmópolis (do cidadão do mundo), a qual colaborava para que o indivíduo não tivesse condições de identificar-se com a sua comunidade.

Do mesmo modo, demonstra-se frívola a proposição da inexistência da distinção de classes, uma vez que seria difícil se admitir que o homem livre e o escravo são iguais, com o argumento de que a verdadeira liberdade encontra-se na razão e, como ela é individual, não poderia ser cerceada.

A apatia, que serve de ideal para os estóicos, gera o alheamento do mundo e esse desapego conduz ao egoísmo. Dentro dessa realidade, o indivíduo não tem qualquer perspectiva em relação ao outro. E isso pode resultar no próprio aniquilamento da vida social.

Tal perspectiva é enfatizada por Giovanni Reale e Dario Antiseri:

A apatia que envolve o estóico é extrema, acabando por se tornar verdadeiramente enregelante e até inumana". [...] A ajuda que o estóico dá aos outros homens só poderá, assim, ser asséptica, longe de qualquer 'simpatia' humana, exatamente como o frio logos deve se mover entre os seus semelhantes em atitude de total distanciamento, seja quando fizer política, seja quando se casar, seja quando cuidar dos filhos, seja quando fizer amizades, acabando por tornar-se estranho à própria vida: com efeito, o estóico não é um entusiasta da vida, nem um amante dela, como o epicurista. ${ }^{34}$

Viu-se que a ausência de delimitação do espaço político, inspirada na filosofia

${ }^{33}$ VALVERDE, op. cit.,p. 118.

${ }^{34}$ REALE; ANTISERI, op. cit., p. 265. 
do estoicismo, ensejou a apatia dos indivíduos. Todavia, ela não só vingou na civilização helenística, mas estendeu-se à civilização romana, influenciando fortemente os seus intelectuais e governantes, atendendo aos seus propósitos hegemônicos, que serão objeto de estudo do próximo item.

\subsection{A CIVILIZAÇÃO ROMANA}

A civilização romana surgiu muito tempo antes do ocaso da civilização grega. Ela já se destacava paralelamente ao tempo das conquistas militares de Alexandre Magno e desenvolveu-se a tal ponto que consolidou sua hegemonia por aproximadamente cinco séculos. Os domínios de Roma, ao final do século I a.C., compreendiam todo o mundo helenístico. ${ }^{35}$

O Mediterrâneo tornou-se o mare nostrum e é através dele que chegam as riquezas oriundas das conquistas militares. Roma conhece nesse período uma grande prosperidade e luxo. O "lago romano" também permite a vinda de muitos estrangeiros, tais como, sírios, egípcios, hebreus, gregos, os quais trouxeram novos valores culturais que iriam influenciar de forma marcante o modo de viver e de pensar romanos, destacando-se a cultura grega. Burns assevera que "Roma edificou uma importante ponte histórica entre o Oriente e o Ocidente". ${ }^{36}$

Contudo, Roma trilhou o seu próprio caminho, premida por duas culturas (a tradição agrícola e a influência grega). A história da civilização romana é caracterizada pela tradição agrícola e pelas conquistas militares e, por outro lado, os romanos cobiçavam a cultura e o luxo dos gregos. ${ }^{37}$ Enquanto essa realidade manifestou-se, os romanos conheceram um período de grande esplendor. ${ }^{38}$

\footnotetext{
${ }^{35}$ BURNS , op. cit., p. 138.

${ }^{36}$ Ibid., p. 139.

${ }^{37}$ Ibid., loc. cit.

${ }^{38}$ Ibid., p. 138.
} 
Após Roma ter vivenciado a experiência monárquica, por volta do final do século VI a.C., ela é substituída pela República. A queda da Monarquia gerou várias modificações no panorama político. O rei foi substituído por dois cônsules, os quais eram funcionários, sendo que o seu número tinha por escopo que um controlasse o outro. Eram eleitos para um mandato de um ano, tendo competência executiva e judiciária. O Senado tem as suas competências ampliadas para "controle sobre os fundos públicos e o poder de veto sobre todos os atos da assembléia". ${ }^{39}$ Na hipótese de ocorrer um conflito entre os cônsules, era facultada a consulta ao Senado para dirimilo. Nos casos de emergência, poderia ser nomeado um ditador, pelo prazo máximo de seis meses.

A República foi um período caracterizado por conflitos bélicos constantes visando a conquista de novos territórios, o que reforçava a característica agrária dos romanos. Tais conflitos ensejaram repercussões negativas no âmbito social, econômico e cultural. Os agricultores dedicavam-se ao serviço militar, e ao fazê-lo, negligenciaram o cultivo da terra, resultando no seu endividamento e na conseqüente perda das suas propriedades. ${ }^{40}$ Isso favoreceu a concentração da renda na mão dos grandes proprietários de terras e, por outro lado, fez com que muitos agricultores se deslocassem para as cidades ou mesmo se sujeitassem a trabalhar como rendeiros nos territórios conquistados.

Ao mesmo tempo, para aplacar as reivindicações econômicas dos plebeus, havia necessidade de conceder-lhes terras e isso somente seria possível através de conquistas militares, pois os patrícios detinham uma parcela considerável das propriedades. O resultado dessas conquistas territoriais foi um extenso Império. Para controlá-lo, havia a necessidade de centralizar o poder político, inclusive facilitando sufocar eventuais insurreições. Com esse intuito, o Senado investiu Júlio César (101-

\footnotetext{
${ }^{39}$ Ibid., p. 143.

${ }^{40}$ José Maria VALVERDE (op. cit, p. 133), assevera que "Res publica significa 'coisa de todos'. Mas da República romana só participavam os patrícios que detinham o poder econômico e militar e, agora, também o político. A plebe - pequenos proprietários, comerciantes e artesãos - e os clientes (espécie de agregados dos patrícios), para não falar de escravos, não tinham acesso ao poder. A história de República é assim uma sucessão de revoltas da plebe que aos poucos foi conquistando direitos políticos, que revertiam em benefícios econômicos".
} 
44 a.C.) na posição de imperator (comandante do Exército) em 46 a.C. ${ }^{41}$

Na civilização romana, tanto na República quanto no Império, verifica-se que as idéias do estoicismo estiveram presentes e influenciaram fortemente as decisões políticas da civilização romana, sobretudo no tocante à participação política.

Foi dentro de um contexto de ócio que nasceu e se desenvolveu o pensamento romano, que era a soma de várias correntes filosóficas, havendo uma preponderância no tocante à moral. Adicione-se a essa falta de originalidade que a produção filosófica romana ficou muito a desejar se comparada à grega, com exceção no campo do direito.

Os principais representantes do estoicismo em Roma foram Cícero, Marco Aurélio, Epíteto e Sêneca, cujas contribuições ocorreram muito mais no campo pragmático do que teórico. $^{42}$

Marcos Túlio Cícero (106 - 43 a.C.) foi orador, advogado, jusfilósofo e renomado político romano, autor das Catilinárias. Para ele, o direito não é produto do arbítrio, mas resulta da natureza. Assim como o direito, o Estado também é fruto da natureza, posto que haveria um instinto natural que impele o homem para a convivência e ação política.

Assim manifestava-se Cícero acerca dessa natureza:

\begin{abstract}
A razão reta, conforme à natureza, gravada em todos os corações, imutável, eterna, cuja voz ensina e prescreve o bem, afasta o mal que proíbe e, ora com seus mandados, ora com suas proibições, jamais se dirige inutilmente aos bons, nem fica impotente ante aos maus. Essa lei não pode ser contestada, nem derrogada em parte, nem anulada; não podemos ser isentos de seu cumprimento pelo povo nem pelo Senado; não há que procurar nela outro comentador nem intérprete; não há uma lei em Roma e outra em Atenas, uma antes e outra depois, mas una, sempre eterna e imutável, entre todos os povos e em todos os tempos; uno será sempre o seu imperador e mestre, que é Deus, seu inventor, sancionador e publicador, não podendo o
\end{abstract}

${ }^{41}$ Dois anos após, foi proclamado ditador vitalício pelo Senado, mas foi assassinado logo depois. Aduz ainda José Maria VALVERDE (op. cit., p. 133-134): "Tal efetiva concentração de poderes em uma só pessoa, esvaziando as demais instituições políticas, representaria, de certa maneira, um alívio para as famílias aristocráticas, já cansadas da onerosa participação no negotium (negócio, que na época significava administração pública); podiam agora gozar do otium (ócio), uma vida sem trabalho proporcionada pela riqueza do Império e pelo emprego da mão-de-obra escrava, e assim dedicar-se à cultura e às artes".

${ }^{42}$ A este respeito vide SANSON (op. cit., p. 135). 
homem desconhecê-la sem renegar-se a si mesmo, sem despojar-se do seu caráter humano e sem atrair sobre si a mais cruel expiação, embora tenha conseguido evitar todos os outros suplícios. $^{43}$

As palavras de Cícero, contudo, não expressam a realidade da prática política romana, como acaba-se de verificar. Se ela efetivamente fosse executada, não legaria a apenas uma classe (a dos patrícios) o direito de participar na gestão da coisa pública.

Por outro lado, a referida classe detinha o poder constituído, eis que votava, executava e julgava. Portanto, era ela quem acabava determinando o que era este Direito Natural conforme a razão e que todos deveriam obedecer. Por este motivo, ao não admitir refutação, ele contribuía para reiterar o seu caráter universal, uma vez que deveria ser aplicado em todos os domínios da civilização romana.

Em outras palavras, o homem deveria resignar-se ao Logos que era manifestado pelo Direito Natural, cuja interpretação e aplicação estava nas mãos dos patrícios e dos governantes, expressando os interesses da elite política. ${ }^{44}$

Marco Aurélio Antonino (121-180 d.C.) foi imperador e autor de Meditações. Dentro da proposta estóica da cosmópolis, aduziu que: "Ora, minha natureza é racional e cívica; eu tenho uma cidade e um país; como Marco, tenho Roma, e como homem tenho o Universo. Por conseqüência, o que é benéfico para estas duas entidades é o

\footnotetext{
${ }^{43}$ CÍCERO. Da república. São Paulo: Nova Cultural, 1988, p. 170.

${ }^{44}$ Este pensamento encontra-se explicitado nas lições de François CHÂTELET et allii, na obra (CHÂTELET, François et allii. História das idéias política desde a Antigüidade. Rio de Janeiro: Zahar, 1985, p. 24-25), ao comentar os princípios que definem a "cidade ecumênica"(=universal) segundo Cícero e as suas conseqüências políticas: "Desse modo, as legislações de fato aparecem, no mais das vezes, como produtos dessa ignorância. O mérito das instituições romanas, contudo, consiste em ter definido a comunidade por elas regida com base num vínculo jurídico e numa ordem política estritamente determinada. Por causa disso, a respublica ganha uma outra consistência: formada por experiência e por reflexão, é também - de certo modo e na medida em que a contingência histórica permite - a expressão da lei natural. A Cidade ecumênica poder assim ser compreendida, enquanto concede progressivamente o direito de cidadania e faz com que os povos conquistados se beneficiem das garantias do direito romano, como o núcleo de uma organização universal que faz de cada indivíduo um cidadão do mundo, um cosmopolita. Sem o querer, Cícero prepara a ordem imperial. E isso em medida tanto maior quanto, retomando o tema da constituição mista, esboça a imagem do princeps, do príncipe-árbitro, "tutor e defensor da respublica". Dezesseis anos depois da morte de Cícero, Otávio Augusto receberá o título de Imperator".
} 
único bem para mim". 45

A partir da frase supratranscrita, constata-se que há uma tentativa de diferenciar Roma do mundo. Todavia, como viu-se anteriormente, tal diferença inexiste, pois o que era o mundo nessa época, senão o próprio domínio romano? ${ }^{46}$

Marco Aurélio pretendia asseverar que, independentemente do local onde o homem estiver domiciliado, ele deve direcionar seus esforços no sentido manter a hegemonia territorial romana e que isso somente poderia acontecer se "apaticamente" aceitasse essa condição. Existiria, ademais, algo mais útil às duas cidades do que o homem aceitar esta condição?

Esse quadro de apatia, reforçado pelas teorizações dos seguidores do estoicismo em Roma, particularmente seus governantes, colabora para que os povos conquistados pelos romanos não se insurgissem contra a dominação e se resignassem com tal condição, perpetuando o status político e militar romano. ${ }^{47}$

${ }^{45}$ (AURÉLIO, Marco. Meditações. São Paulo: Iluminuras, 1995, p. 67). No mesmo sentido: "Pensa nos milhares daqueles que sofreram inimizades, suspeitas, animosidades conflitos e que agora estão mortos e são pó e cinza, e não te agites mais. Ou por acaso estás descontente com a parte do Universo que te cabe? Lembra-te mais uma vez do dilema: 'se não há uma Providência, então apenas um conjunto de átomos’, e considera que o mundo é apenas uma cidade" (op. cit., p. 37-39)

46 Neste sentido, Ernst CASSIRER, na obra ( $O$ mito do Estado. Lisboa: Europa-América, 1961, p. 134): "Como podia o filósofo estóico conservar a sua independência de pensamento, a sua autonomia, o seu juízo firme e imperturbado, no turbilhão das paixões e na arena das lutas políticas? Mas não foi desta maneira que os escritores romanos, homens como Cícero, Sêneca e Marco Aurélio, compreenderam e interpretaram o ideal estóico. Para eles não existia quebra de continuidade entre a esfera individual e política. E isto porque estavam convencidos de que a realidade tomada como um conjunto tanto a realidade física como a vida moral, era uma grande `república'. Esta república é a mesma para todas as nações, a mesma para deuses e homens. Todos os seres racionais são membros da mesma comunidade. 'Universus hic mundus', dizia Cícero, 'una civitas communis deorum atque hominum existimanda est'. Aquele que vive em harmonia consigo mesmo, com o seu 'demônio', diz Marco Aurélio, vive em harmonia com o universo. A ordem universal e a pessoal nada mais são do que diferentes manifestações de um princípio comum subjacente".

${ }^{47}$ George H. SABINE (op. cit., p. 156, 158-159), discorre acerca desta peculiaridade: "Nenhum outro sistema grego era tão apropriado como o estoicismo para encaixar com as virtudes originárias de domínio de si mesmo, devoção ao dever e espírito público de que se orgulhavam especialmente os romanos, e nenhuma concepção política estava tão bem qualificada como a doutrina estóica do estado universal para introduzir um certo idealismo no negócio, demasiado sórdido, a conquista romana. O ponto de contato no momento crítico - a terça quarta parte do século II - apoiou na relação dos gregos, Panécio e Políbio, amigos pessoais, com o grupo de aristocratas romanos que formavam o círculo de Escipião Emiliano. [...] Tão pouco cabe dúvida de que o estado universal dos estóicos se prestava com facilidade a uma espécie de imperialismo sentimental que permitiu aos 
Este quadro de apatia política, fruto da influência do estoicismo, não estaria completo sem o pensamento de Epíteto (50-130 d.C.), ex-escravo que, após sua alforria, se dedica à Filosofia. Ele aduzia que era necessário separar aquilo que depende de nós e o que não depende.

Afirma em seu Manual: "'Depende de nós’", ‘a opinião, a tendência, o desejo, a aversão, em uma palavra, tudo o que é obra nossa; não dependem de nós o corpo, a riqueza, os testemunhos de consideração, os altos cargos, em uma palavra, o que não é obra nossa'. Trata-se então de conduzirmos corretamente tudo o que depende de nós e permanecermos indiferentes quanto ao resto: nisto consistiriam a tranqüilidade da alma e a felicidade". ${ }^{48}$ Pelo que se infere, os próprios escravos, mesmo na condição de libertos, incentivavam o desapego à pólis e à sua participação, renunciando aos cargos públicos e a tudo que estivesse fora da sua dimensão interior.

Na medida em que as leis são desnecessárias, consoante viu-se anteriormente nas concepções de Zenão de Cítio, inexiste a necessidade da participação dos cidadãos para deliberarem sobre a sua elaboração, muito menos participar da administração da coisa pública.

Paulo Nader consegue sintetizar as conseqüências do estoicismo, a partir de tais premissas: "Pelos princípios gerais do estoicismo se depreende a existência de um Direito Natural, que seria aquele em total harmonia com a razão que governa o universo. Com a implantação do Estado único, o Direito Natural tenderia a se efetivar espontaneamente, prescindindo de leis, pois estas não seriam mais necessárias,

conquistadores imaginar-se que não faziam senão assumir o que a teoria política de língua inglesa tem denominado 'a carga do homem branco' (white man's burden) e que estavam levando os benefícios da paz e da ordem ao mundo politicamente incompetente. Por último, no fim do século II a.C. houve uma circunstância histórica especial - as reformas intentadas por Tibério Graco no ano de 133, mediante uma apelação franca de interesses opostos das classes econômicas - que fazia o recurso a uma concordia ordinum, uma reação própria dos republicanos aristocratas. A teoria da forma mista de governo tem uma grande importância no pensamento de Cícero, porém nele não é já senão a remota esperança da República. A linha direta seguida pelo desenvolvimento destas idéias sob o Império legou a cidadania romana a todos os súditos imperiais, feita mediante o Edito de Caracala no ano de 212 d.C., e a abolição das distinções existentes entre classes. O igualitarismo implícito neste movimento é muito mais conforme ao espírito do estoicismo romano que a forma adotada temporariamente pelo estoicismo sob a influência de Panécio e Políbio".

\footnotetext{
${ }^{48}$ VALVERDE, op. cit., p. 138.
} 
conforme o pensamento do fundador da Escola". ${ }^{49}$

Em outras palavras, o estoicismo institucionaliza a apatia política, interditando a atuação dos indivíduos no panorama político, uma vez que o Logos manifestado pelo Direito Natural se encarregará de fazê-lo através dos detentores do poder constituído e daqueles cujos interesses representam. Ele será interpretado e aplicado no sentido de legitimar a apatia dos indivíduos no plano político e a dominação dos povos conquistados. Impõe ao indivíduo conformar-se com essa situação, com o status de "cidadão do mundo" - o mundo romano é claro - mas para tanto deverá aceitar a sua abstinência no plano político.

A partir das análises que se fez da influência da proposta cosmopolita do estoicismo nas civilizações helenística e romana, foi possível constatar que o indivíduo não mais participava e nem se preocupava com os destinos da sua comunidade, uma vez que a participação era desestimulada pelas próprias práticas despóticas dos dirigentes daquelas civilizações, bem como pelos teóricos do estoicismo, que afirmavam que o indivíduo era um cidadão do mundo, da cosmópolis, e que deveria afastar-se de tudo aquilo que o ligava ao Estado, na esteira do ideal de apatia dos estóicos.

Tal panorama, no qual o indivíduo estava alheado dos destinos da sua comunidade, pois não participava politicamente, fazia com que a produção do direito ficasse nas mãos dos dirigentes das civilizações helenística e romana, o que facilitava a sua manipulação em seu próprio benefício, sendo favorecido pelo comportamento apático dos indivíduos. No tocante aos pensadores estóicos, verifica-se que uma vez implantado o Estado Universal, sem fronteiras, o Direito Natural se efetivaria, sendo desnecessária a existência de leis, ${ }^{50}$ ou seja, a participação do indivíduo na votação das leis seria estéril.

Pode-se inferir que o cosmopolitismo dos estóicos cerceou a participação política, engendrada pela apatia que seus defensores propugnavam.

\footnotetext{
${ }^{49}$ NADER, op. cit., p. 113.

${ }^{50}$ Ibid., loc. cit.
} 


\section{O ADVENTO DE UMA NOVA PROPOSTA COSMOPOLITA: A GLOBALIZAÇÃO}

O presente item pretende traçar as transformações e tensões entre participação política e delimitação territorial ou, pelos seus opostos, apatia e mundo sem fronteiras. Dessas tensões e transformações, procura-se indicar a plausibilidade da utilização das idéias do cosmopolitismo estóico como instrumento de análise de alguns elementos da globalização no que se refere à participação política.

\subsection{A GLOBALIZAÇÃO}

Primeiramente, é importante salientar algumas dificuldades epistemológicas e metodológicas para analisar o fenômeno da globalização. A globalização teve várias concepções ao longo do tempo. Mesmo hoje, pode-se encontrar várias significações para o mesmo fenômeno.

Além disso, em que pese a profícua produção bibliográfica sobre o tema, sobretudo nos últimos anos, ainda não foi produzido um marco teórico que possibilitasse a leitura da globalização de forma cabal. ${ }^{51}$

Ao proceder-se o levantamento bibliográfico das obras, constata-se um grande ecletismo teórico nas abordagens sobre o tema, sem qualquer pretensão de sistematização, salvo em pouquíssimas obras, como por exemplo, nas de Boaventura de Sousa Santos. ${ }^{52}$

${ }^{51}$ Neste sentido, a resenha da obra José Luís FIORI et allii (Globalização: o fato e o mito. Rio de Janeiro: EdUERJ, 1998), sintetiza o problema: "Não há dúvida de que a palavra globalização foi cunhada no campo próprio das ideologias, transformando-se, nesta última década, num lugarcomum de enorme conotação positiva, apesar de sua visível imprecisão conceitual. É provável, inclusive, que esta palavra passe à história dos modismos sem jamais adquirir um verdadeiro estatuto teórico, mantendo-se como um conceito inacabado".

${ }^{52}$ Destaca-se a obra SANTOS, Boaventura de Sousa. La globalización del derecho: los nuevos caminos de la regulación y la emancipación. Bogotá: Universidad Nacional de Colombia, 
Uma vez que se pretende analisar a realidade transnacional, encontra-se ainda outro obstáculo de natureza epistemológica decorrente do fato de que a Sociologia sempre teve o âmago das suas reflexões centrado no âmbito nacional, conforme destacado por Ulrich Beck ${ }^{53}$ e Octavio Ianni, o qual assevera:

Os desafios epistemológicos suscitados pela formação e transformação da sociedade nacional, alimentaram a emergência e continuam a alimentar o desenvolvimento das ciências sociais, constituindo os fundamentos de seu patrimônio. A maior parte dos conceitos, categorias e leis formulados pelas ciências sociais tem por base as relações, os processos e as estruturas de dominação e apropriação, integração e antagonismo, soberania e hegemonia peculiares à realidade nacional. As principais teorias da sociedade, tais como a evolucionista, positivista, funcionalista, marxista, weberiana, estruturalista e sistêmica, entre outras, tomam por base relações, processos e estruturas próprios da sociedade nacional, como um todo ou em alguns dos seus aspectos. Apoiadas nessas teorias, a economia, política, geografia, demografia, sociologia, antropologia e história, entre outras ciências sociais, constituíram e continuam a constituir uma parte importante de seu patrimônio teórico. 'A sociologia, conforme ela aparece no seio da civilização ocidental e como a conhecemos hoje, é endemicamente preocupada com o nacional. Não reconhece uma totalidade mais ampla que a organizada politicamente na nação. O termo 'sociedade', como tem sido usado por sociólogos, independentemente da filiação teórica, é para todos os fins práticos o nome de uma entidade idêntica, em tamanho e composição, ao estado-nação. ${ }^{54}$

Outra dificuldade encontrada na análise da temática é de natureza metodológica. ${ }^{55} \mathrm{Na}$ esteira do que já se ressaltou anteriormente, sobre o ponto de vista epistemológico, encontra-se grandes dificuldades, ao reduzir o fenômeno da globalização a uma categoria, para possibilitar sua análise. Tal obstáculo decorre do fato de que, partindo-se de vários enfoques teóricos, nem sempre a globalização é compreendida da mesma forma. Evidentemente, em face da ausência de um marco teórico, metodologicamente, optou-se por analisar a globalização como um tipo ideal, o qual faz parte das teorizações de Max Weber. O conceito de tipo ideal faz parte das

1998.

${ }^{53}$ BECK, Ulrich. Qué es la globalización. Barcelona: Paidós, 1998, p. 46, 48.

${ }^{54}$ IANNI, Octavio. Nação e globalização. In: SANTOS, Milton et alllii. Fim de século e globalização. 3. ed. São Paulo: Hucitec, 1997. p. 68.

${ }^{55}$ Adotamos o método teórico-reflexivo, uma vez que trabalharemos com categorias teóricas, bem como desenvolveremos uma análise empírico-crítica, contextualizada no cotidiano. 
teorizações de Max Weber, o qual foi muito bem sintetizado por Juan Carlos Agulla. ${ }^{56}$

Concebe-se a globalização como uma crescente interconexão em vários níveis da vida cotidiana a diversos lugares longínquos no mundo. ${ }^{57}$ A globalização possui várias dimensões. Dente elas a dimensão política, social, ambiental e cultural, sendo que centrar-se-á o enfoque na globalização econômica, a qual entende-se que é o fio condutor das demais dimensões, bem como por permitir desvendar a crise dos Estados nacionais. $^{58}$

Observa-se que a globalização econômica que se vivencia é peculiar pela velocidade, extensão, interconexão da movimentação de mercadorias e informações ao redor do mundo, nunca antes visto na história, na esteira das lições de John Gray. ${ }^{59}$ Tais fatores contribuíram para o aumento da internacionalização do comércio, produzindo um crescimento gigantesco no comércio mundial, em tal proporção que tornou os Estados impotentes para controlar os fluxos de capitais, cuja dinâmica rompe ou ultrapassa as fronteiras estatais, fazendo com que as fronteiras nacionais começassem a perder sentido.

Este novo panorama é identificado como tendo se iniciado após a Segunda Guerra Mundial, se consolidando na década de oitenta. Todavia, deve-se considerar que a fixação de data para a manifestação do fenômeno da globalização, trata-se de uma conveniência histórica, em face da impossibilidade da sua determinação exata,

56 Juan Carlos AGULLA analisa o tipo ideal de Weber na sua obra (Teoría sociológica: sistematización histórica. Buenos Aires: Depalma, 1987, p. 207-208): "Os tipos ideais são conceitos construídos racionalmente a partir da experiência, que contêm os caracteres mais gerais e típicos da ação. É dizer: são elementos obtidos da realidade empírica, porém em seu conjunto estranhos a ela. São como uma caricatura: mostram os traços mais importantes, exagerando-os. Com a ajuda destes tipos se pode chegar a estabelecer como se desenvolveria a ação se o fizera com todo o rigor como saída ao fim, sem perturbação alguma. Porém, a realidade é mais complexa, como tipo ideal só se pode indicar o grau de aproximação entre a construção ideal e o desenvolvimento real, facilitando a compreensão do sentido dos fatos, justamente por sua racionalidade".

57 Esta concepção está baseada na definição do termo dada por Anthony GIDDENS na obra (As conseqüências da modernidade. São Paulo: UNESP, 1999, p. 69).

${ }^{58}$ Acerca das dimensões da globalização, vide VIEIRA, Liszt. Cidadania e globalização. 2. ed. Rio de Janeiro: Record, 1997.

${ }^{59}$ GRAY, John. Falso amanhecer: os equívocos do capitalismo global. Rio de Janeiro: Record, 1999, p. 84. 
consoante as lições de Hobsbawm. ${ }^{60}$

Neste contexto, as empresas transnacionais tornam-se protagonistas privilegiadas no mundo globalizado, em face do poder por elas detido, fazendo frente ao poder dos Estados. Surge uma nova divisão internacional do trabalho, ${ }^{61}$ a qual contribui para o reforço deste poder, fazendo com que a produção se dissemine em vários países, tornando obsoletas as fronteiras dos Estados e reduzindo o seu poder.

John Gray descreve com precisão este poder detido pela empresas transnacionais:

O crescimento e o poder das corporações multinacionais são enormes e sem precedentes. As multinacionais são hoje responsáveis por um terço da produção mundial e dois terços do comércio mundial. Mais importante é que cerca de um quarto do comércio mundial ocorre

${ }^{60}$ Com relação a fixação de data para a manifestação do fenômeno da globalização, trata-se de uma conveniência histórica, em face à impossibilidade da sua determinação exata, sendo importante levar-se em consideração as lições de Eric HOBSBAWM, na sua obra (O novo século. São Paulo: Cia. das Letras, 2000, p. 9-10): "[...] As datas exatas sempre são questões de conveniência histórica, didática ou jornalística. [...] Em outras palavras, a escolha de uma data específica não passa de uma convenção, e não é algo pelo qual os historiadores estejam dispostos a brigar".

${ }^{61}$ A este respeito assevera Pierre BOURDIEU, em A precariedade está hoje por toda a parte. (Contrafogos: táticas para enfrentar a invasão neoliberal. Rio de Janeiro: Zahar, 1998, p. 124125): "Facilitando ou organizando a mobilidade do capital, e o 'deslocamento' para os países com salários mais baixos, onde o custo do trabalho é reduzido, favoreceu-se a extensão da concorrência entre os trabalhadores em escala mundial. A empresa nacional (ou até nacionalizada), cujo território de concorrência estava ligado, mais ou menos estritamente, ao território nacional, e que saía para conquistar mercados no estrangeiro, cedeu lugar à empresa multinacional, que põe os trabalhadores em concorrência, não mais apenas com seus compatriotas, ou mesmo, como querem nos fazer crer os demagogos, com os estrangeiros implantados no território nacional, que, evidentemente, são de fato as primeiras vítimas da precarização, mas com trabalhadores do outro lado do mundo, que são obrigados a aceitar salários de miséria. A precariedade se inscreve num modo de dominação de tipo novo, fundado na instituição de uma situação generalizada e permanente de insegurança, visando obrigar os trabalhadores à submissão, à aceitação da exploração. Apesar de seus efeitos se assemelharem muito pouco ao capitalismo selvagem das origens, esse modo de dominação é absolutamente sem precedentes, motivando alguém a propor aqui o conceito ao mesmo tempo muito pertinente e muito expressivo de flexploração. Essa palavra evoca bem essa gestão racional da insegurança, que, instaurando, sobretudo através da manipulação orquestrada do espaço da produção, a concorrência entre os trabalhadores dos países com conquistas sociais mais importantes, com resistências sindicais mais organizadas - características ligadas a um território e a uma história nacionais - e os trabalhadores dos países menos avançados socialmente, acaba por quebrar as resistências e obtém a obediência e a submissão, por mecanismos aparentemente naturais, que são por si mesmos a sua própria justificação. Essas disposições submetidas produzidas pela precariedade são a condição de uma exploração cada vez mais 'bem-sucedida', fundada na divisão entre aqueles que, cada vez mais numerosos, não trabalham, e aqueles que, cada vez menos numerosos, trabalham, mas trabalham, cada vez mais". 
dentro de corporações multinacionais. Em 1993, de acordo com um levantamento das Nações Unidas, a produção das multinacionais girou em torno de 5,5 trilhões de dólares - o mesmo valor do que os Estados Unidos como um todo.

[...] Elas são capazes de dividir o processo de produção em discretas operações e localizá-las em diversos países ao redor do mundo. Elas são menos dependentes do que nunca das condições nacionais. Elas podem escolher os países cujos mercados de trabalho, impostos e sistemas regulamentadores e infra-estrutura sejam considerados mais adequados. A promessa de investimento interno direto e a ameaça de sua retirada têm grande influência nas opções políticas dos governos nacionais. As empresas podem agora limitar as políticas dos Estados. Existem poucos precedentes históricos deste tipo de poder privado. ${ }^{62}$

\subsection{O NEOLIBERALISMO}

Para se compreender a globalização, deve-se também analisar o neoliberalismo, uma vez que suas políticas operacionalizam a globalização econômica. Trata-se de uma política econômica que surgiu no final da Segunda Guerra Mundial, no denominado Consenso de Washington, consubstanciada basicamente nas seguintes medidas: liberação dos mercados, desregulamentação, minimalismo estatal, controle da inflação, primazia das exportações, cortes nas despesas sociais, redução do déficit público, concentração do poder mercantil nas grandes empresas multinacionais e do poder financeiro nos grandes bancos transnacionais. Para a consecução de tais objetivos, foram criados alguns organismos internacionais: GATT, Banco Mundial e FMI.

Os principais teóricos do neoliberalismo são os economistas Hayek e Milton Friedman, fundadores da Sociedade de Mont Pelèrin, que preconizam basicamente a instauração de um Estado mínimo, que se incumba de funções reduzidas, desde que se garanta uma sociedade de livre mercado em âmbito internacional, contribuindo tais teorizações para a implementação da globalização econômica.

O papel do Estado seria o de garantir e proteger o livre mercado, reduzindo-se e/ou suprimindo-se as tutelas estatais no âmbito social. Segundo os corifeus do neoliberalismo, no embate entre a democracia e a liberdade, vista a última sob o

\footnotetext{
${ }^{62}$ GRAY, op. cit., p. 86.
} 
enfoque econômico, esta deveria prevalecer.

A aplicação das medidas econômicas de cunho neoliberal na Inglaterra, nos governos Thatcher, foi extremamente nefasta sob o ponto de vista das repercussões sociais. O êxito da experiência chilena é identificado como decorrente do caráter antidemocrático, autoritário e conservador imprimido pela ditadura de Pinochet.

\subsection{A CRISE E/OU DECLÍNIO DO ESTADO-NAÇÃO}

Com o advento da globalização econômica, pode-se constatar a crise ou o declínio do Estado-nação, decorrente da transnacionalização da economia implementada pelo fenômeno da globalização econômica, respaldada pela teoria econômica do neoliberalismo, em face da gradual erosão da soberania, da obsolência das fronteiras nacionais, do retraimento da esfera pública em favor do mercado e da perda dos direitos políticos dos cidadãos como resultado do esvaziamento da sua participação política.

Apresentar-se-á alguns elementos indicativos da crise ou declínio do Estadonação e da soberania, decorrentes da transnacionalização da economia.

Hobsbawm sintetiza o panorama do declínio do Estado-nação asseverando que:

Quando a economia transnacional estabeleceu o seu domínio sobre o mundo, solapou uma grande instituição, até 1945 praticamente universal: o Estado-nação territorial, pois um Estado assim já não poderia controlar mais que uma parte cada vez menor dos seus assuntos. Organizações cujo campo de ação era efetivamente limitado pelas fronteiras de seu território, como sindicatos, parlamentos e sistemas públicos de rádio e televisão nacionais, saíram portanto perdendo, enquanto organizações não limitadas desse jeito, como empresas transnacionais, o mercado de moeda internacional e os meios de comunicação da era do satélite, saíram ganhando. O desaparecimento das superpotências, que podiam de qualquer modo controlar os Estados-satélites, iria reforçar essa tendência. Mesmo a mais insubstituível função que os Estados-nações haviam desenvolvido durante o século, a de redistribuir sua renda entre suas populações através das 'tendências sociais' dos serviços de previdência, educação e saúde, e outras alocações de fundos, não mais podia ser 


\section{COSMOPOLITISMO E GLOBALIZAÇÃO: \\ EFEITOS NA SEARA POLÍTICO-JURÍDICA CONTEMPORÂNEA}

territorialmente auto-suficiente em teoria, embora a maior parte tivesse de continuar sendo na prática, a não ser onde entidades supranacionais como a Comunidade ou União Européia a complementasse em alguns aspectos. Durante o auge dos teólogos do livre mercado, o Estado foi solapado mais ainda pela tendência de desmontar as atividades então exercidas, em princípio, por órgãos públicos deixando-as entregues ao 'mercado'. ${ }^{63}$

Os sintomas da crise ou do declínio do Estado-nação, em face das transnacionalização da economia, também são constatados por Boaventura de Sousa Santos, sobretudo enunciando as mazelas da globalização dela decorrentes no plano político-jurídico:

[...] Ao contrário do que aconteceu em tempos passados, a força diretriz por trás da transformação do Estado e da sua legalidade é a intensificação das práticas transnacionais e as interações globais; sob essas pressões, as funções reguladoras do Estado-nação passariam a ser derivadas, é dizer, passam a depender dos imperativos da globalização econômica tal como são formulados pelas organizações internacionais (o Banco Mundial, a Organização Mundial do Comércio, o Fundo Monetário Internacional, etc.) ou pelas próprias empresas multinacionais dos estados hegemônicos, na defesa dos interesses destas, sobretudo as norteamericanas. Um exemplo desta situação encontra-se na pressão dos Estados Unidos em favor da adoção de novas leis sobre patentes a nível global. Nesta circunstância, a regulação estatal, sobretudo na periferia e na semi-periferia do sistema mundial, se converte numa espécie de subcontratação ou franquia política.

[...] A ideologia e a prática do liberalismo econômico impulsionada por forças políticas domésticas e internacionais, combinadas com as práticas das empresas transnacionais, têm levado certamente a uma perda relativa do papel de protagonista do Estado-nação dentro do sistema mundial. A maioria dos autores tendem a aceitar que, em áreas decisivas, o Estado está sendo desconectado tanto do capital como do trabalho nacionais, perdendo a sua capacidade de garantir por si mesmo os ajustes institucionais necessários para a uma reprodução e uma acumulação estáveis. [...]. ${ }^{64}$

Neste sentido, consoante Boaventura, a concepção de soberania perde todo o sentido no mundo globalizado:

[...] a operação dos Estados num sistema internacional cada vez mais complexo limita sua autonomia (em certas esferas de forma radical) e menospreza progressivamente sua soberania. Todas as concepções que interpretam a soberania como uma forma de poder

${ }^{63}$ HOBSBAWM, Eric. A era dos extremos. 2. ed. São Paulo: Cia. das Letras, 1998, p. 413414.

${ }^{64}$ SANTOS, Boaventura de Sousa. La globalización del derecho ..., p. 37, 87. 
público ilimitado e indivisível - materializado canonicamente nos Estados-nação individuais - resultam obsoletas. A soberania tem que ser concebida hoje em dia como uma faculdade dividida entre múltiplas agências - nacionais, regionais e internacionais - e limitada pela natureza mesma desta pluralidade. ${ }^{65}$

Esta perda da soberania e da eficácia dos Estados-nação não corresponde, na visão de Boaventura de Sousa Santos, a um aumento de poder nas esferas transnacionais para a solução dos problemas globais:

A perda da centralidade institucional e de eficácia reguladora dos Estados nacionais, por todos reconhecida, é hoje um dos obstáculos mais resistentes à busca de soluções globais. É que a erosão do poder dos Estados nacionais não foi compensada pelo aumento de poder de qualquer instância transnacional com capacidade, vocação e cultura institucional voltadas para a resolução solidária dos problemas globais. De fato, o caráter dilemático da atuação reside precisamente no fato da perda de eficácia dos Estados nacionais se manifestar antes na incapacidades destes para construírem instituições internacionais que colmatem e compensem essa perda de eficácia. ${ }^{66}$

Os motivos da deterioração do Estado-nação, consoante Hobsbawm, seriam os seguintes:

[...] algumas características do panorama político global se destacavam. A primeira, como já se observou, era o enfraquecimento do Estado-nação, instituição central da política desde a Era das Revoluções devido a tanto seu monopólio do poder público e da lei quanto porque constituía o campo efetivo da ação política para a maioria dos fins. O Estado-nação estava sendo erodido de duas formas, de cima e de baixo. Perdia rapidamente poder e função para várias entidades supranacionais, e, na verdade, de forma absoluta, na medida em que a desintegração de grandes Estados e impérios produzia uma multiplicidade de Estados menores, demasiado fracos para defender-se numa era de anarquia internacional. Perdia também, como vimos, seu monopólio de poder efetivo e seus privilégios históricos dentro de suas fronteiras, como testemunham a ascensão da segurança privada e dos serviços postais privados competindo com o correio, até então praticamente controlado em toda a parte por um ministério de Estado. ${ }^{67}$

65 HELD, David. La democracia y el orden global: del Estado moderno al gobierno cosmopolita. Barcelona: Paidós, 1997, p. 169.

${ }^{66}$ SANTOS, Boaventura de Sousa. Pela mão de Alice: o social e o político na pósmodernidade. 2. ed. São Paulo: Cortez, 1996, p. 300.

${ }^{67}$ HOBSBAWM, Eric. A era dos extremos ..., p. 553-554. 
Concorda-se com Octavio Ianni quando reconhece a limitação da soberania do Estado-nação e o abalo na sua base, ${ }^{68}$ não aceitando a idéia do seu fim, pois tais categorias seriam criadas e recriadas pelo capitalismo, consoante suas necessidades.

A partir do poder das empresas transnacionais, presencia-se uma ruptura histórica que marca o declínio do Estado-nação e o surgimento de "novos e poderosos centros mundiais de poder, soberania e hegemonia". Entende-se que, na esteira do pensamento de Ianni, mesmo assim, o Estado-nação continuaria existindo, porém com um novo significado: as funções do Estado permanecem no âmbito da globalização, todavia, o seu papel tende a reduzir-se gradativamente, havendo uma redefinição do mesmo, porém com um novo significado, ou seja, nada mais seria do que um emblema, uma ficção:

Ocorre que a economia-mundo, ou sistema-mundo, em toda a sua complexidade não só econômica, mas também social, política e cultural, sempre transcende tudo o que é local, nacional e regional. Repercute por todos os cantos, perto e longe. Os colonialismos e imperialismos espanhol, português, holandês, belga, francês, alemão, russo, japonês. inglês e norte-americano sempre constituíram e destruíram fronteiras, soberanias e hegemonias, compreendendo tribos, clãs, nações e nacionalidades. São muitos os que reconhecem nos Estados nacionais asiáticos, africanos e latino-americanos foram desenhados, em sua quase totalidade, pelos colonialismos e imperialismos europeus, segundo modelos geo-histórico e teórico, ou ideológico, configurado no Estado-nação que se formou e predominou na Europa.

O emblema o Estado-nação sempre teve as características simultâneas e contraditórias de realidade geo-histórica e ficção. Na época da globalização, e provavelmente de forma muito mais marcante, torna-se mais ficção. Tal emblema está atravessado por relações, processos e

68 A este respeito, Octavio IANNI (Teorias da globalização. 2. ed. Rio de Janeiro: Civilização Brasileira, 1996, p. 34) afirma: "Quando se leva às últimas conseqüências 'o princípio da maximização da acumulação do capital', isto se traduz em desenvolvimento intensivo e extensivo das forças produtivas e das relações de produção, em escala mundial. Desenvolvem-se relações, processos e estruturas de dominação política e apropriação econômica em âmbito global, atravessam os territórios e fronteiras, nações e nacionalidades. Tanto é assim que as organizações multilaterais passam a exercer as funções de estruturas mundiais de poder, ao lado das estruturas mundiais de poder constituídas pelas corporações transnacionais. É claro que não se apagam o princípio da soberania nem o estado-nação, mas são radicalmente abalados em suas prerrogativas, tanto que se limitam drasticamente, ou simplesmente anulam, as possibilidades de projetos de capitalismo nacional e socialismo nacional. Acontece que o capitalismo, enquanto modo de produção e processo civilizatório, cria e recria o Estado-nação, assim como o princípio da soberania que define a sua essência. Ainda que esta entidade, isto é, o Estado-nação soberano, permaneça, ou mesmo recrie, está mudando de figura, no âmbito das configurações e movimentos da sociedade global. Aliás, não é por acaso que se multiplicam os estudos e os debates acerca do Estado-nação, enquanto processo histórico e invenção, uma realidade persistente e problemática; e que se encontra em crise no final do século XX, quando da globalização do capitalismo". 
estruturas altamente determinados pela dinâmica dos mercados, da desterritorialização das coisas, gentes e idéias, enquanto a reprodução ampliada do capital se globaliza, devido ao desenvolvimento extensivo e intensivo do capitalismo, compreendendo as forças produtivas, tais como o capital, a tecnologia, a força de trabalho e a divisão do trabalho social, sempre envolvendo as instituições, os padrões socioculturais e os ideais relativos à racionalização, produtividade, lucratividade, quantidade. ${ }^{69}$

\subsection{AS CONSEQÜÊNCIAS NO PLANO POLÍTICO-JURÍDICO}

As análises da globalização econômica e do neoliberalismo são relevantes, pois propiciam a abordagem das conseqüências causadas no plano político-jurídico, ${ }^{70}$ decorrentes do processo de transnacionalização do espaço político decorrente da globalização, quando a noção de política perde o seu referencial de manifestação num espaço político definido territorialmente, transcendendo as fronteiras do Estado-nação.

Viu-se, no item anterior, que o processo de elaboração das decisões políticas, engendrado pela globalização e pelas políticas neoliberais, cerceia o poder de decisão do Estado, permanecendo refém das diretrizes estabelecidas pelos organismos internacionais e pelas empresas transnacionais.

Constata-se, ainda, que os cidadãos ficam impedidos de definirem os rumos da sociedade, esvaziando a sua participação política, peculiaridades que expressam o esvaziamento do poder local, representado pelo retraimento da esfera pública, cedendo espaço à esfera privada identificada com o mercado, colocando em risco o futuro da política, da democracia e da solidariedade, ensejando desestruturação e fragmentação social.

As conseqüências negativas desse panorama caminham no sentido de que os cidadãos, na medida em que dele se conscientizam, cada vez mais perceberiam que

${ }^{69}$ Ibid, , p. 40-41.

${ }^{70}$ Para uma análise mais profunda das conseqüências negativas da globalização nas searas política e jurídica, vide o capítulo III da obra do autor (LIMA, Abili Lázaro Castro de. Globalização econômica, política e direito: análise das mazelas no plano político-jurídico. Porto Alegre: Fabris, 2002). 
seria estéril o debate e a tomada de decisões políticas no âmbito local, seja ele um país, uma província ou uma cidade. O centro das decisões estaria longe ${ }^{71}$ e os cidadãos sentiriam cada vez mais que sua vida está interditada no plano político-participativo.

Será que haveria lugar para cidadãos num mundo globalizado?

Viu-se que as fronteiras tendem a serem derrubadas pela globalização visando possibilitar o fluxo dos capitais e, notadamente, facilitar a aquisição de produtos.

A partir dessa realidade, constata-se que com a globalização, os cidadãos se tornariam meros "consumidores". Alain Touraine demonstra esta infeliz condição e suas conseqüências nefastas para a democracia:

A democracia foi conquistadora quando colocou suas esperanças na razão e no trabalho para combater os privilégios e tradições. Atualmente, está mais inquieta porque a globalização esmaga a diversidade das culturas e experiências pessoais e porque o cidadão se transforma em consumidor. Inquieta, sobretudo, porque está saindo de um longo período de dominação dos regimes totalitários ou autoritários que impuseram seu poder absoluto em nome de uma revolução popular e porque, hoje em dia, no próprio interior das sociedades que são protegidas do arbitrário, exercem-se forças que destróem a democracia. A opinião pública pode se transformar em consumo de programas e a defesa do indivíduo pode se degradar em particularismos, seitas ou até mesmo, obsessão de identidade pessoal ou coletiva. A separação crescente entre mundo dos objetos e mundo da cultura faz desaparecer o sujeito que se define pela produção de sentido a partir da atividade, pela transformação de uma situação em ação e em produção de si. A democracia não é a submissão do indivíduo ao bem comum; pelo contrário, coloca as instituições a serviço da liberdade e da responsabilidade pessoais. No entanto, temos dificuldade de perceber o espaço do sujeito entre as massas que o enquadram e ameaçam esmagá-lo: por um lado, as filiações sociais e culturais, por outro, o mercado ou os sistemas técnicos. A crise da modernidade vem do fato de deixarmos de nos sentir donos do mundo que construímos: este impõe-nos sua lógica, a do lucro ou a do poder, de modo que, para lhe oferecer resistência, devemos fazer apelo ao que há de menos moderno em nós e mais ligado a uma história e comunidade. ${ }^{72}$

${ }^{71}$ A este respeito assevera Ignacio RAMONET, em (O pensamento único e os regimes globalitários. In: FIORI, José Luís et allii. Globalização: o fato e o mito. Rio de Janeiro: EdUERJ, 1998. p. 74): "As pessoas têm consciência de que estão infelizes e que o poder está muito longe; elas têm a impressão de que não estão sendo reconhecidas, nem ouvidas por aqueles que têm os meios de agir e de protestar. Constatam que a maior parte das sociedades continuam estruturadas por armaduras jurídicas e políticas elaboradas no alvorecer da era industrial, no final do século XVIII e durante o século XIX. Essas armaduras revelam-se impotentes, hoje, para traduzir a complexidade das sociedades inervadas por múltiplas redes que aceleram a informação, transformam a cultura, perturbam o trabalho, os valores, os modos de vida. [...] A aceleração é tanta, em certa áreas, que a confusão, o ceticismo ganham os espíritos. O quadro político em geral mostra-se, por comparação, imóvel, petrificado, obsoleto".

\footnotetext{
72 TOURAINE, Alain. O que é a democracia? Petrópolis: Vozes, 1995, p. 178-179.
} 


\section{O cidadão, no âmbito da globalização, também é visto por Octavio Ianni na}

condição de consumidor, conforme se infere de suas teorizações:

De fato, é inegável a contradição entre ascetismo e consumismo, se pensamos no capitalismo em perspectiva weberiana. Ao longo da história, à medida que se desenvolve o capitalismo, o ascetismo parece declinar e o consumismo hedonista crescer. Isto significa que a matriz originária do capitalismo, sintetizada na ética protestante, na profissão como vocação e no ascetismo como negação do hedonismo, progressivamente rotiniza-se, seculariza-se e dissolve-se no jogo das forças sociais presentes e crescentes no mercado. Assim, aos poucos, o consumismo se constitui em outra esfera de dinamização das ações, relações, instituições e organizações sociais, em escala local, nacional, regional e mundial. No âmbito do consumismo é que se desenvolve a sociedade de consumo, a sociabilidade consumista, em que indivíduos e multidões imaginam que estão realizando cidadania, confundindo a liberdade e a igualdade de consumidores com os direitos do cidadão. ${ }^{73}$

Robert W. McChesney evidencia esta condição de consumidor dos cidadãos, a partir do neoliberalismo:

Por outro lado, para ser efetiva, a democracia requer que as pessoas sintam uma comunicação com seus concidadãos, e que esta conexão manifeste ela mesma através de uma variedade de organizações e instituições não-mercantis. Uma cultura política vibrante necessita de grupos comunitários, bibliotecas, escolas públicas, organizações de bairro, cooperativas, locais de encontro público, associações de voluntários e sindicatos para proporcionar caminhos aos cidadãos de encontrar, comunicar, e interagir com seus concidadãos. A democracia neoliberal, como a sua noção de mercado über alles (acima de tudo), faz morrer o objetivo neste setor. O resultado líquido é uma sociedade atomizada de indivíduos desengajados que se sentem desmoralizados e socialmente impotentes.

Em resumo, o neoliberalismo é o imediato e primeiro inimigo da democracia genuinamente participatória, não somente nos Estados Unidos mas através do planeta, e será para o futuro previsível. ${ }^{74}$

Assim, o cidadão, na qualidade de consumidor, ${ }^{75}$ uma vez que sua vida

${ }^{73}$ IANNI, Octavio, Teorias da globalização ..., p. 125.

74 McCHESNEY, Robert W. Introdução. CHOMSKY, Noam. Profit over people: neoliberalism and global order. New York: Seven Stories, 1999. p. 11.

${ }^{75}$ Assevera ainda Alain TOURAINE (op. cit., p. 203): "Outrora, acreditava-se que era preciso sacrificar seus interesses pessoais para ser um bom cidadão e, ainda mais, um bom revolucionário; atualmente, devemos afirmar praticamente o contrário. A massa de apoio aos dominadores é constituída por aqueles cujo comportamento se reduz a uma participação passiva no consumo; somente os que são individuados, que são sujeitos, estão em condições de opor um princípio 
política estaria cerceada e, paralelamente, o mundo a sua volta o instigaria a consumir, passaria então a ter como meta a busca da satisfação de suas necessidades consumistas. $^{76}$

Neste contexto, a satisfação da busca de um bem, ensejaria a busca de outro. O indivíduo ficaria inserido como numa roda-viva, na busca de consumir cada vez mais. Ele se voltaria cada vez mais para si mesmo, despertando um comportamento egoísta, que foi também percebido por Eric J. Hobsbawm ao analisar as transformações sofridas pelo mundo no final do "Breve Século XX":

\begin{abstract}
A terceira transformação, em certos aspectos a mais perturbadora, é a desintegração de velhos padrões de relacionamento social humano, e com ela, aliás, a quebra dos elos entre as gerações, quer dizer, entre passado e presente. Isso ficou muito evidente nos países mais desenvolvidos da versão ocidental de capitalismo, onde predominaram os valores de um individualismo associal absoluto, tanto nas ideologias não oficiais, embora muitas vezes aqueles que defendem esses valores deplorem suas conseqüências sociais. Apesar disso, encontravam-se as mesmas tendências em outras partes, reforçadas pela erosão das sociedades e religiões tradicionais e também pela destruição, ou autodestruição, das sociedades do 'socialismo real'.

Essa sociedade, formada por um conjunto de indivíduos egocentrados sem outra conexão entre si, em busca apenas da própria satisfação (o lucro, o prazer ou seja lá que for), estava sempre implícita na teoria capitalista. Desde a Era da Revolução, observadores de todos os matizes ideológicos previram a conseqüente desintegração dos velhos laços sociais na prática e acompanharam seu desenvolvimento. É conhecido o eloqüente tributo do Manifesto Comunista ao papel revolucionário do capitalismo ("A burguesia [...] despedaçou impiedosamente os diversos laços feudais que ligavam o homem ao homem além do puro interesse próprio’..). ${ }^{77}$
\end{abstract}

E, nesse turbilhão consumista, ${ }^{78}$ o indivíduo esqueceria a sua condição de

de resistência à dominação dos sistemas".

${ }^{76}$ Este comportamento consumista pode impor riscos à própria democracia, conforme adverte Alain TOURAINE (op. cit., p. 205): "Neste final do século XX, nos países industrializados e ricos, o perigo principal é que a democracia se degrade em um mercado político no qual os consumidores procurem os produtos que lhes convenham. Tal situação não é democrática porque é dominada por um sistema de ofertas que se dissimulam em demandas sociais".

${ }^{77}$ HOBSBAWM, Eric J. A era dos extremos: o breve século XX 1914-1991. 2. ed. São Paulo: Companhia das Letras, 1996, p. 24-25.

${ }^{78}$ Edgar MORIN e Anne Brigitte KERN (Terra-pátria. 2. ed. Porto Alegre: Sulina, 1995, p. 88-89) retratam este quadro consumista do mundo globalizado: "A cidade-luz, que oferece liberdades e variedades, torna-se igualmente a cidade tentacular, cujas coerções, a começar pelas da casa/metrô/trabalho, sufocam a existência, e cujo estresse acumulado esgota os nervos. A vida 
cidadão, ou seja, de participar da vida pública. Torna-se um mero súdito, passivo e conformado com esta realidade.

Com certo gosto de cinzas na boca, se assistiria, na medida em que a globalização iria se incrementando, uma crescente apatia política que geraria a morte da política, bem como da democracia, a qual Touraine também vislumbrou:

Hoje em dia, está desfeito o equilíbrio frágil entre Estado, sociedade política e sociedade civil. A globalização dos mercados, a construção européia e o longo período de guerra fria retiraram do sistema político sua capacidade de decisão, enquanto o Estado torna-se a cabeça de um corpo da batalha econômica, científica, militar e política que defende os interesses nacionais em um cenário internacional cada vez mais competitivo e perigoso.

Nessas condições, surgem dois riscos: o primeiro tem a ver com a desagregação da sociedade política e da sociedade civil, reduzidas ambas ao estado de mercados. A população pode renunciar aos encargos da cidadania e contentar-se com os prazeres do consumo de massa, pedindo ao Estado para servir de policial benevolente que distribuiria socorros aos excluídos da mudança econômica e garantiria a segurança das pessoas de bem. O segundo é o contrário: a sociedade pode se fechar sobre si mesma, transformando-se em comunidade e exigir a formação de um Estado comunitário, como é possível ver no Afeganistão, quanto na Sérvia ou Croácia. Nos dois casos, a democracia desaparece. No primeiro, lentamente, na medida em que seu desaparecimento é simulado pela sensibilidade dos decididores às reações da opinião; no segundo, de forma brutal, porque o Estado comunitário define-se pela supressão do sistema político e pela busca de uma homogeneidade cultural e política que rejeita os direitos das minorias e a própria idéia de cidadania. Da mesma forma que devemos apoiar a consciência nacional que exige a construção de um Estado nacional democrático, assim também devemos condenar os Estados comunitários. É fácil admitir o direito dos sérvios e croatas a disporem de si mesmos, a se separarem da Federação Iugoslava em decomposição e a criarem um Estado nacional, mas com a condição de que esse Estado

democrática regride. Quanto mais os problemas adquirem uma dimensão técnica, tanto mais escapam às competências dos cidadãos em proveito dos especialistas. Quanto mais os problemas de civilização se tornam políticos, tanto menos os políticos são capazes de integrá-los em sua linguagem e em seus programas. O homem produtor está subordinado ao homem consumidor, este ao produto vendido no mercado, e este último a forças libidinais cada vez menos controladas no processo circular no qual se cria um consumidor para o produto e não mais apenas um produto para o consumidor. Uma agitação superficial se apodera dos indivíduos assim que escapam às coerções escravizantes do trabalho. $\mathrm{O}$ consumo desregrado torna-se superconsumo insaciável que alterna com curas de privação; a obsessão dietética e a obsessão com a forma física multiplicam os temores narcísicos e os caprichos alimentares, sustentam o culto dispendioso das vitaminas e dos oligo-elementos. Entre os ricos o consumo se torna histérico, maníaco pelo prestígio, a autenticidade, a beleza, a tez pura, a saúde. Eles percorrem as vitrines, os grandes magazines, os antiquários, os mercados de pulgas. A bibelomania se conjuga com a bugigangomania. Os indivíduos só pensam no dia de hoje, consomem o presente, deixam-se fascinar por mil futilidades, tagarelam sem jamais se compreender na torres de Babel das bugigangas. Incapazes de ficar quietos, lançam-se em todos os sentidos. O turismo é menos a descoberta do outro, a relação física com o planeta, do que um trajeto sonambólico guiado num mundo semifantasma de folclores e monumentos. A 'diversão' moderna mantém o vazio que ela quer evitar". 


\section{COSMOPOLITISMO E GLOBALIZAÇÃO: \\ EFEITOS NA SEARA POLÍTICO-JURÍDICA CONTEMPORÂNEA}

reconheça os direitos fundamentais dos cidadãos e, em particular, os direitos das minorias. ${ }^{79}$

\section{Eric J. Hobsbawm também denuncia a crescente despolitização e apatia} política engendrada pelo consumo no âmbito da globalização:

Por sua própria natureza, a sociedade de consumo contemporânea cada vez mais obriga as estruturas políticas a se adaptarem a ela. Na verdade, a teoria do livre mercado alega que não há necessidade da política, pois a soberania do consumidor deve prevalecer sobre todo o resto: o mercado supostamente deve garantir o máximo de escolhas para os consumidores, permitindo-lhes satisfazer todas as suas necessidades e desejos por meio dessas escolhas. Esse caminho ignora o processo político, torna-o um efeito colateral , ou derivado, do mercado. Este é o motivo da tremenda difusão de ocupações como relações públicas e assessoria política, e da aplicação à política de sistemas como os focus groups, que na verdade se baseiam nas pesquisas de mercado.

Isto coloca em crise a própria função da cidadania. Se os consumidores são capazes de alcançar seus objetivos pelo exercício cotidiano de seu poder de escolha ou pela indicação de suas opiniões aos mecanismos de consulta da mídia, o que resta exatamente da cidadania? Há ainda alguma necessidade de mobilizar grupos de pessoas para a realização de objetivos políticos?

Essa evolução do mercado destrói a própria base dos procedimentos políticos. O estabelecimento de uma relação direta entre o ponto mais baixo do sistema, o consumidor, e o ponto mais alto, o responsável pelas decisões políticas, não deixa nenhum espaço para a essência da política, definida por Habermas como a organização da 'esfera pública' na qual as pessoas articulam suas opiniões e se unem para alcançar objetivos coletivos. Isto, em outras palavras, é tudo o que até agora entendemos por política nas sociedades liberais e democráticas. ${ }^{80}$

\section{Milton Santos reflete acerca do individualismo e egoísmo que decorrem deste} quadro consumista presente na globalização, elucidando o seu perfil nos seguintes termos:

Nos últimos cinco séculos de desenvolvimentos e expansão geográfica do capitalismo, a concorrência se estabelece como regra. Agora, a competitividade toma o lugar da competição. A concorrência atual não é mais a velha concorrência, sobretudo porque chega eliminando toda forma de compaixão. A competitividade tem a guerra como norma. Há, a todo custo, que vencer o outro, esmagando-o, para tomar seu lugar. Os últimos anos do século XX foram emblemáticos, porque neles se realizaram grandes concentrações, grandes fusões, tanto na órbita da produção como das finanças e da informação. Esse movimento

\footnotetext{
${ }^{79}$ TOURAINE, op. cit., p. 265-266.

${ }^{80}$ HOBSBAWM, Eric J. O novo século ..., p. 118-119.
} 
marca um ápice do sistema capitalista, mas é também indicador do seu paroxismo, já que a identidade dos atores, até então mais ou menos visível, agora finalmente aparece aos olhos de todos.

Essa guerra como norma justifica toda forma de apelo à força, a que assistimos em diversos países, um apelo não dissimulado, utilizado para dirimir os conflitos e conseqüência dessa ética da competitividade que caracteriza nosso tempo. Ora, é isso também que justifica os individualismos arrebatadores e possessivos: individualismos na vida econômica (a maneira como as empresas batalham umas com as outras); individualismos na ordem política (a maneira como os partidos freqüentemente abandonam a idéia de política para se tornarem simplesmente eleitoreiros); individualismos na ordem do território (as cidades brigando umas com as outras, as regiões reclamando soluções particularistas). Também na ordem social e individual são individualismos arrebatadores e possessivos, que acabam por constituir o outro como coisa. Comportamentos que justificam todo desrespeito às pessoas são, afinal, uma das bases da sociabilidade atual. Aliás, a maneira como as classes médias, no Brasil, se constituíram entroniza a lógica dos instrumentos, em lugar da lógica das finalidades, e convoca aos pragmatismos a que se tornam triunfantes. ${ }^{81}$

\section{A leitura da globalização e do neoliberalismo realizada por Boaventura de}

Sousa Santos também vislumbra que o consumismo nelas presente, reproduz um cenário de individualismo, o qual prevalece em detrimento da cidadania, causando profundas transformações nos valores pessoais e da própria sociedade:

Apesar de todas as diferenças, o regresso do princípio do mercado nos últimos vinte anos representa a validação social e política do ideário liberal e, conseqüentemente, a revalorização da subjetividade em detrimento da cidadania. Também neste domínio a resposta do capital aproveita e distorce sabiamente algumas das reivindicações dos movimentos contestatórios dos últimos trinta anos. A aspiração da autonomia, criatividade e reflexividade é transformada em privatismo, dessocialização e narcisismo, os quais, acoplados à vertigem produtivista, servem para integrar, como nunca, os indivíduos na compulsão consumista. Tal integração, longe de significar uma cedência materialista, é vivida como expressão de um novo idealismo, um idealismo objetístico. A natureza do consumo metaforseia-se. Para além de que alguns objetos de consumo não têm qualquer existência material (as imagens digitais, por exemplo), a retração da produção em massa e a sua gradual substituição pela clientelização e personalização dos objetos transforma estes em características da personalidade de quem os usa e, nessa medida, os objetos transitam da esfera do ter para a esfera do ser. O novo subjetivismo é objetístico e o culto dos objetos é o Ersatz da intersubjetividade. Estas transformações são de tal modo profundas e arquetípicas que, para dar adequadamente contra elas, é necessário proceder a transformações também profundas e arquetípicas na teoria sociológica. Nas condições sociais dos anos noventa, o idealismo será provavelmente a forma mais conseqüente do materialismo. ${ }^{82}$

${ }^{81}$ SANTOS, Milton. Por uma outra globalização: do pensamento único à consciência universal. Rio de Janeiro: Record, 2000, p. 46-47.

${ }^{82}$ SANTOS, Boaventura de Sousa. Pela mão de Alice ..., p. 255-256. 


\title{
COSMOPOLITISMO E GLOBALIZAÇÃO: \\ EFEITOS NA SEARA POLÍTICO-JURÍDICA CONTEMPORÂNEA
}

Este panorama geraria uma situação perversa na sociedade, segundo Milton

Santos, que poderia redundar na morte da política:

\begin{abstract}
Na verdade, a perversidade deixa de se manifestar por fatos isolados, atribuídos a distorções de personalidade, para se estabelecer como um sistema. Ao nosso ver, a causa essencial da perversidade sistêmica é a instituição, por lei geral da vida social, da competitividade como regra absoluta, uma competitividade que escorre sobre todo o edifício social. O outro, seja ele uma empresa, instituição ou indivíduo, aparece como um obstáculo à realização dos fins de cada um e deve ser removido, por isso sendo considerado uma coisa. Decorrem daí a celebração dos egoísmos, o alastramento dos narcisismos, a banalização da guerra de todos contra todos, com a utilização de qualquer que seja o meio para obter o fim colimado, isto é, competir e, se possível, vencer. Daí a difusão, também generalizada, de outro subproduto da competitividade, isto é, a corrupção.
\end{abstract}

Esse sistema da perversidade inclui a morte da Política (com um P maiúsculo), já que a condução do processo político passa a ser atributo das grandes empresas. Junte-se a isso o processo de conformação da opinião pelas mídias, um dado importante no movimento de alienação trazido com a substituição do debate civilizatório pelo discurso único do mercado. Daí o ensinamento e o aprendizado de comportamentos dos quais estão ausentes objetivos finalísticos e éticos.

Assim elaborado, o sistema de perversidade legitima a preeminência de uma ação hegemônica mas sem responsabilidade, a instalação sem contrapartida de uma ordem entrópica, com a produção 'natural' da desordem.

Para tudo isso, também contribui o estabelecimento do império do consumo, dentro do qual se instalam consumidores mais que perfeitos (M. Santos, O espaço do cidadão, 1988), levados à negligência em relação à cidadania e seu corolário, isto é, o menosprezo quanto à liberdade, cujo culto é substituído pela preocupação com a incolumidade. Esta reacende egoísmos e é um dos fermentos da quebra da solidariedade entre as pessoas, classes e regiões. Incluam-se, também, nessa lista dos processos característicos a instalação do sistema da perversidade, a ampliação das desigualdades de todo gênero: interpessoais, de classes, regionais, internacionais. Âs antigas desigualdades, somam-se novas. ${ }^{83}$

É oportuno, neste momento, resgatar-se aquilo que já se havia enfatizado no item 3.1., na análise da globalização econômica. Asseverou-se que ela seria o fio condutor das demais manifestações de globalização, aduzindo que as dimensões política, social, ambiental e cultural estavam imbricadas na globalização econômica. Salientou-se, naquela oportunidade, a importância da análise da globalização econômica, eis que ela permitiria elucidar as mazelas da globalização do plano político-participativo e jurídico.

${ }^{83}$ SANTOS, Milton. Op. cit, p. 60-61. 
Ocorre que o consumismo e o individualismo, presentes na globalização, causam efeitos maléficos no plano político-participativo, consoante viu-se anteriormente. Neste particular, pode-se constatar que a globalização econômica articula-se com a globalização cultural, evidenciando as seqüelas nocivas, peculiaridade que corrobora o escopo neste capítulo, e que também podem ser vislumbradas a partir das lições de Peter Beilharz:

Considero significativa a distinção entre palavras e coisas, porque parecemos estar lidando com dois processos conectados - globalização econômica e globalização cultural - que talvez devam ser diferenciados. Embora a cultura seja obviamente mediada pela economia, talvez seja no domínio da globalização cultural que encontremos inicialmente o pósmoderno, na forma de uma cultura de consumo. Pretendo argumentar, o que pode ser embaraçoso para pessoas como nós, o fato de que talvez desejássemos celebrar a globalização cultural ou o trânsito entre as culturas, porém, ao mesmo tempo, sabemos que a globalização econômica envolve um ataque frontal contra a social-democracia, pois a socialdemocracia e seu campo de ação, as reivindicações por cidadania e direitos sociais são, em grande parte, experiências nacionais. O socialismo, por conta disso, está em apuros, pois por um século ele foi inserido na política de formação de nações, uma política que, hoje, foi declarada globalmente dispensável. ${ }^{84}$

Néstor García Canclini, ao realizar um estudo da globalização a partir da perspectiva cultural, também identifica a perspectiva na qual o cidadão assume o papel de consumidor e que as decisões políticas são tomadas em função do apelo consumista presente no mundo globalizado:

[...] Muito do que é feito atualmente nas artes é produzido e circula de acordo com as regras das inovações e da obsolência periódica, não por causa do impulso experimentador, como no tempo das vanguardas, mas sim por que as manifestações culturais foram submetidas aos valores que 'dinamizam' o mercado e a moda: consumo incessantemente renovado, surpresa e divertimento. Por razões semelhantes a cultura política tornou-se errática: desde que se tornaram raros os relatos emancipadores que viam as ações presentes como parte de uma história e procura de um futuro renovador, as decisões políticas e econômicas são tomadas em função das seduções imediatistas do consumo, o livre comércio sem memória de seus erros, a importação afobada dos últimos modelos que nos faz cair, uma e outra vez, como se cada uma fosse a primeira, no endividamento e na crise da balança de pagamentos. ${ }^{85}$

${ }^{84}$ BEILHARZ, Peter. Globalização, bem-estar e cidadania. In: OLIVEIRA, Francisco de; PAOLI, Maria Célia. Os sentidos da democracia: políticas do dissenso e hegemonia global. Petrópolis: Vozes, 1999. p. 178.

85 CANCLINI, Néstor García. Consumidores e cidadãos: conflitos multiculturais da 
A partir desta perspectiva, Canclini reflete sobre os vínculos entre o consumo e a cidadania, ${ }^{86}$ no âmbito da globalização, constatando que os direitos ligados à cidadania ficam restritos àqueles que têm acesso ao consumo, resultando num quadro de apatia política:

[...] Pela imposição da concepção neoliberal de globalização, para a qual os direitos são desiguais, as novidades modernas aparecem para a maioria apenas como objetos de consumo, e para muitos apenas como espetáculo. O direito de ser cidadão, ou seja, de decidir como são produzidos, distribuídos e utilizados esses bens, se restringe novamente às elites.

[...] Nas nações onde o voto é voluntário, mais da metade da população se abstém nas eleições; onde é obrigatório, as pesquisas revelam que 30 a $40 \%$ não sabem em quem votar uma semana antes dos comícios. Se as manifestações nas ruas e nas praças diminuem, e se dispersam em múltiplos partidos, movimentos juvenis, indígenas, feministas, de direitos humanos e tantos outros, ficamos com a última parte da questão: onde está o povo?

Além do mais, quando aquilo que chamamos 'o povo' vota, surge uma outra pergunta inquietante: por que líderes que empobreceram as maiorias conseguem preservar o consenso entre as massas prejudicadas? Não há apenas uma explicação. Trata-se antes de montar um quebra-cabeças: entender como as forças hegemônicas vêm conseguindo se situar nos cenários estratégicos da economia, da política e da comunicação, onde as sociedades desta segunda metade do século XX se transformaram. [...]. ${ }^{87}$

Essa condição de consumidor assumida pelo cidadão no mundo globalizado constitui uma subversão às conquistas políticas obtidas no seio do Estado moderno. Ela desagrega a sociedade como um todo, uma vez que se perdem os elos de solidariedade que uniam os indivíduos uns com os outros, peculiaridade que lhes dava o sentimento de pertencimento a uma Nação, bem como de identidade, dentro do seu espaço territorial, substituindo-o por comportamentos de individualismo, egoísmo e

globalização. 3. ed. Rio de Janeiro: UFRJ, 1997, p. 1.

${ }^{86}$ Néstor García CANCLINI (op. cit., p. 55), traz um exemplo concreto desta vinculação entre o consumo e cidadania: "Percebe-se também a importância política do consumo quando vemos políticos que detiveram a hiperinflação na Argentina, no Brasil e no México centrarem sua estratégia de consumo na ameaça de que uma mudança de orientação econômica afetaria aqueles que se endividaram comprando a prazo carros ou aparelhos eletrodomésticos: 'Se não querem que a inflação volte, aumentem as taxas de juros e não consigam continuar pagando o que compraram, devem votar em mim novamente', diz Carlos Menem ao tentar a reeleição para a Presidência da Argentina. Uma fórmula empregada na campanha eleitoral 'o voto-prestação' exibe a cumplicidade que existe hoje entre consumo e cidadania".

${ }^{87}$ Ibid., p. 30, 32. 
apatia política engendrados pelo consumo. ${ }^{88}$

Assim, pode-se inferir, levando-se em consideração os riscos que a democracia e a política estariam correndo, que ficaria seriamente comprometida a atuação dos indivíduos no processo de formação do direito, uma vez que o locus institucional da criação das leis é o Parlamento.

Em resumo, a partir das teorizações anteriormente vistas, na globalização, o indivíduo viveria num mundo onde as fronteiras dos Estados teriam perdido o significado, onde não haveria discriminação em relação à origem dos indivíduos, onde todos seriam vistos como "iguais", buscando a satisfação de suas necessidades próprias, cujo ideal seria o consumo e que geraria um mero súdito apático no que tange ao âmbito político-participativo.

Obviamente, essa condição de igualdade trata-se de mera falácia ideológica, posto que, como seria possível todos os indivíduos serem iguais no mundo globalizado, se a possibilidade de acesso ao consumo não é estendida a todos? Em outras palavras, o pré-requisito para tornar-se cidadão no mundo globalizado é ter condições de consumir, peculiaridade que é, por si só, eloqüente para demonstrar seu caráter segregador. $^{89}$

${ }^{88}$ (Ibid., p. 61-62) ao discorrer sobre esta condição do cidadão no mundo globalizado, identifica as comunidades transnacionais de consumidores que dela decorre: "Contudo, estas comunidades de pertencimento e controle estão se reestruturando. A que conjunto a participação numa sociedade construída predominantemente pelos processos de globalizados de consumo nos faz pertencer? Vivemos um tempo de fraturas e heterogeneidade, de segmentações dentro de cada nação e de comunicações fluídas com as ordens transnacionais da informação, da moda e do saber. Em meio a esta heterogeneidade encontramos códigos que nos unificam, ou que ao menos permitem que nos entendamos. Mas esses códigos compartilhados são cada vez menos os da etnia, da classe ou da nação em que nascemos. Essas velhas unidades, na medida em que subsistem, parecem se reformular como pactos móveis de leitura dos bens e das mensagens. Uma nação, por exemplo, a esta altura é pouco definida pelos limites territoriais ou por sua história política. Sobrevive melhor como uma comunidade hermenêutica de consumidores, cujos hábitos tradicionais fazem com que se relacione de um modo peculiar com os objetos e a informação circulante nas redes internacionais. Ao mesmo tempo encontramos comunidades internacionais de consumidores - já mencionamos as de jovens e telespectadores - que dão sentido de pertencimento quando se diluem as lealdades nacionais".

${ }^{89}$ Ignacio RAMONET, na obra (Geopolítica do caos. 2. ed. Petrópolis: Vozes, 1998, p. 6667) evidencia este quadro ao aduzir: "O outro paradigma é o mercado. Ele substitui o de máquina, de relógio, de organização, cujos mecanismos e funcionamento garantiam a evolução de um sistema. Em um relógio, nenhuma peça está a mais e todos os elementos, todas as peças são solidárias. A essa metáfora mecânica, herdada do século XVIII (a sociedade é um 'relógio social' e cada indivíduo 
COSMOPOLITISMO E GLOBALIZAÇÃO:

EFEITOS NA SEARA POLÍTICO-JURÍDICA CONTEMPORÂNEA

Por derradeiro, objetivando demonstrar as mazelas no plano político causadas pela globalização, resta revelar as conseqüências deletérias deste panorama individualista e egoísta causadas pelo consumismo engendrado pela globalização e pelo neoliberalismo, no âmbito do espaço público, o qual estaria gradualmente sendo privatizado e colocado fora do alcance das pessoas, ${ }^{90}$ peculiaridades que foram muito bem sintetizadas por Boaventura de Sousa Santos ao asseverar: "[...] O capitalismo é hoje menos um modo de produção que um modo de vida. O individualismo e o

exerce uma função útil para o bom funcionamento do conjunto) sucede a metáfora econômica e financeira. Daqui em diante, tudo deve ser regulado segundo os critérios de 'Sua Majestade o mercado', panacéia última. Na primeira fila dos novos valores: o lucro, os benefícios, a rentabilidade, a concorrência, a competitividade. As 'leis' do mercado tomam lugar das leis da mecânica (que rege a vida dos astros, do cosmos e da natureza), ou da história, como explicação geral do movimento das sociedades. Aí também, somente os mais fortes é que levam a melhor, com toda a legitimidade, e os mais fracos são excluídos. A vida é uma luta, uma selva. Darwinismo econômico e darwinismo social (apelos constantes à competição, à seleção, à adaptação) impõem-se como se tudo fosse evidente. Nessa nova ordem, os indivíduos dividem-se em 'solvíveis' e 'não-solvíveis', isto é, aptos ou não para integrar o mercado, Este só oferece salvação aos solváveis. Os outros têm vocação para serem rejeitados, expulsos, marginalizados, excluídos, porque na nova configuração social (que deixou de fazer da solidariedade um imperativo), os 'perdedores' podem ser recusados".

${ }^{90}$ Reproduzimos a seguir uma interessante leitura desta perspectiva apresentada por Noam CHOMSKY, na obra (Profit over people: neoliberalism and global order. New York: Seven Stories Press, 1999, p. 131-132): "Nas democracias de Estado capitalista, a arena pública tem sido estendida e enriquecida por um longo e penoso esforço popular. Enquanto isso o poder privado concentrado tem trabalhado para restringi-lo. Estes conflitos formam uma boa parte da história moderna. O modo mais efeito de restringir a democracia é transferir a tomada de decisão da arena pública para incontáveis instituições: reis e príncipes, castas astutas, juntas militares, partidos ditatoriais, ou modernas corporações. As decisões tomadas pelos diretores da GE (General Electric) afetam substancialmente a sociedade em geral, mas os cidadãos não tomam nenhuma parte nelas, como uma questão de princípio (nós podemos colocar de lado o mito transparente sobre o mercado e a "democracia" dos acionistas). Sistemas de incontáveis poderes realmente oferecem algumas opções aos cidadãos. Eles podem peticionar ao rei ou ao Conselho de Conselheiros Econômicos (CEO - Council of Economic Advisors) ou aderir a uma ação do partido governista. Eles podem arrendar-se eles mesmos à GE, ou comprar seus produtos. Eles podem lutar por direitos no interior de tiranias, Estado e de forma privada, ou solidária com outros, pode procurar limitar ou desmantelar o poder ilegítimo, perseguindo ideais tradicionais, incluindo aqueles que animaram o movimento trabalhista dos Estados Unidos desde as suas origens: que aqueles que trabalham nas fábricas deveriam possuí-las e fazê-las operar. A 'corporatização da América' durante o século passado tem sido um ataque à democracia - e nos mercados, parte a mudança de alguma coisa que se assemelha ao 'capitalismo' para os mercados altamente administrados da era moderna do estado/corporação. Uma variável circulante é chamada 'minimizar o estado', que é, transferir o poder de tomada de decisões da arena pública para outro lugar qualquer: 'para as pessoas', na retórica do poder, para tiranias privadas, no mundo real. Todas essas medidas são designadas para limitar a democracia para domesticar a 'multidão covarde', como a população foi chamada pela sua própria auto-designação 'best quality man' (homens da melhor qualidade) durante o primeiro repentino crescimento da democracia no período moderno, na Inglaterra do século XVII, os 'homens responsáveis', como eles se auto-intitulam hoje. Os problemas básicos persistem, constantemente tomando novas formas, clamando para o futuro novas medidas de controle 
consumismo transferiram para a esfera privada a equação entre interesse e capacidade. É nessa esfera que hoje os indivíduos identificam melhor os seus interesses e as capacidades para lhes dar satisfação. A redução à esfera privada desta equação faz com que muitas das desigualdades e opressões que ocorrem em cada um dos espaços-tempo estruturais sejam invisíveis, ou se visíveis, trivializadas". ${ }^{91}$

\section{CONCLUSÃO}

Como visto, o objetivo foi apresentar o cosmopolitismo dos estóicos, tendo como referencial as civilizações helenística e romana, para servir como um instrumento teórico na análise e avaliação de alguns aspectos da globalização na contemporaneidade.

Para alcançar tal objetivo, observou-se a influência do estoicismo nas civilizações helenística e romana, notadamente no que pertine à idéia de mundo sem fronteiras e à apatia que ela despertava no âmbito político. Além disso, teve-se oportunidade de ver o surgimento de uma nova proposta cosmopolita (a globalização), decorrente da relativização dos limites das fronteiras nacionais (elemento constitutivo da idéia de Estado-nação), como resultado da transnacionalização da economia mundial a partir do fim da Segunda Guerra Mundial, notadamente, com o final da Guerra Fria. A globalização foi apresentada como um fenômeno em que se pode vislumbrar o distanciamento dos centros decisórios, o enfraquecimento do poder local e o comprometimento dos níveis jurídico-políticos da participação, peculiaridade que contribuiu para a apatia política dos cidadãos.

A partir de tais evidências, constatou-se as tensões e transformações entre participação política/delimitação territorial e apatia política/mundo sem fronteiras. O artigo procurou demonstrar, a partir de tais tensões/transformações, a plausibilidade da

e marginalização, e conduzindo a novas formas de lutas populares".

${ }^{91}$ SANTOS, Boaventura de Sousa. Pela mão de Alice ..., p. 320. 
utilização das idéias do cosmopolitismo estóico como instrumento para tornar inteligível e possibilitar a análise de alguns elementos da globalização, no que se refere à participação política. Assim sendo, objetivou-se instigar a reflexão sobre a possibilidade de aprofundamento de estudos e pesquisas acadêmico-científicas, no sentido de desvelar a presença de relações entre o cosmopolitismo e a globalização.

Ao apresentar o quadro funesto que se denota no plano político-jurídico com a globalização econômica, a presente reflexão visa alertar as suas consequiências extremamente nefastas para o destino da humanidade. Mas, se tais ocorrências negativas continuarem se manifestando e recrudescerem, o homem poderia ser comparado com o aprendiz da balada imortal de que nos falou Couture, "que sabia provocar tempestades, porém não sabia como contê-las". ${ }^{92}$ Pode-se usar também as palavras do aprendiz de feiticeiro de Goethe: "Os espíritos que eu chamei, destes não me livro mais". ${ }^{93}$

\section{REFERÊNCIAS}

AGULLA, Juan Carlos. Teoría sociológica: sistematización histórica. Buenos Aires: Depalma, 1987.

AURÉLIO, Marco. Meditações. São Paulo: Iluminuras, 1995.

BECK, Ulrich. Qué es la globalización. Barcelona: Paidós, 1998.

BEILHARZ, Peter. Globalização, bem-estar e cidadania. In: OLIVEIRA, Francisco de; PAOLI, Maria Célia. Os sentidos da democracia: políticas do dissenso e hegemonia global. Petrópolis: Vozes, 1999. p. 177-205.

BOURDIEU, Pierre. Contrafogos: táticas para enfrentar a invasão neoliberal. Rio de Janeiro: Zahar, 1998.

BURNS, Edward McNall. História da civilização ocidental. 31. ed. Rio de Janeiro:

\footnotetext{
${ }^{92}$ COUTURE, Eduardo. Os mandamentos do advogado. Porto Alegre: Fabris, 1979, p. 42.

93 "Die ich rief die Geister, werd'ich nun nicht los".
} 
Globo, 1989. v. 1.

CANCLINI, Néstor García. Consumidores e cidadãos: conflitos multiculturais da globalização. 3. ed. Rio de Janeiro: UFRJ, 1997.

CASSIRER, Ernst. O mito do Estado. Lisboa: Europa-América, 1961.

CHÂTELET, François et allii. História das idéias política desde a Antigüidade. Rio de Janeiro: Zahar, 1985.

CHOMSKY, Noam. Profit over people: neoliberalism and global order. New York: Seven Stories Press, 1999.

CÍCERO. Da república. São Paulo: Nova Cultural, 1988.

COUTURE, Eduardo. Os mandamentos do advogado. Porto Alegre: Fabris, 1979.

FASSÒ, Guido. Historia de la filosofía del derecho. 3. ed. Madrid: Pirâmide, 1982. v. 1

FIORI, José Luís et allii. Globalização: o fato e o mito. Rio de Janeiro: EdUERJ, 1998.

FRIEDRICH, Carl J. Perspectiva histórica da filosofia do direito. Rio de Janeiro: Zahar, 1965.

GIDDENS, Anthony. As conseqüências da modernidade. São Paulo: UNESP, 1999.

GRAY, John. Falso amanhecer: os equívocos do capitalismo global. Rio de Janeiro: Record, 1999.

HELD, David. La democracia y el orden global: del Estado moderno al gobierno cosmopolita. Barcelona: Paidós, 1997.

HOBSBAWM, Eric J. A era dos extremos: o breve século XX 1914-1991. 2. ed. São Paulo: Companhia das Letras, 1996.

2. ed. São Paulo: Cia. das Letras, 1998.

. O novo século. São Paulo: Cia. das Letras, 2000.

IANNI, Octavio. Nação e globalização. In: SANTOS, Milton et alliii. Fim de século e globalização. 3. ed. São Paulo: Hucitec, 1997. p. 66-74.

. Teorias da globalização. 2. ed. Rio de Janeiro: Civilização Brasileira, 1996.

LIMA, Abili Lázaro Castro de. Globalização econômica, política e direito: análise das mazelas no plano político-jurídico. Porto Alegre: Fabris, 2002. 
McCHESNEY, Robert W. Introdução. CHOMSKY, Noam. Profit over people: neoliberalism and global order. New York: Seven Stories, 1999. p. 3-5.

MONDIN, Battista. Curso de filosofia. 7. ed. São Paulo: Paulus, 1982. v. 1.

MORIN, Edgar; KERN, Anne Brigitte. Terra-pátria. 2. ed. Porto Alegre: Sulina, 1995.

NADER, Paulo. Filosofia do direito. 2. ed. Rio de Janeiro: Forense, 1992.

PADOVANI, Umberto; CASTAGNOLA, Luís. História da filosofia. 15. ed. São Paulo: Melhoramentos, 1990.

RAMONET, Ignácio. Geopolítica do caos. 2. ed. Petrópolis: Vozes, 1998.

. O pensamento único e os regimes globalitários. In: FIORI, José Luís et allii. Globalização: o fato e o mito. Rio de Janeiro: EdUERJ, 1998. p. 2.

REALE, Giovanni; ANTISERI, Dario. História da filosofia. 2. ed. São Paulo: Paulinas, 1990. v. 1.

RUSSEL, Bertrand. História da filosofia ocidental. São Paulo: Nacional, 1957. l. 1.

SABINE, George H. História de la teoria política. México: Fondo de Cultura Economica, 1945.

SANSON, Vitorino Félix. Estoicismo e cristianismo. Caxias do Sul: EDUCS, 1988.

SANTOS, Boaventura de Sousa. La globalización del derecho: los nuevos caminos de la regulación y la emancipación. Bogotá: Universidad Nacional de Colombia, 1998.

Cortez, 1996.

Pela mão de Alice: o social e o político na pós-modernidade. 2. ed. São Paulo:

SANTOS, Milton. Por uma outra globalização: do pensamento único à consciência universal. Rio de Janeiro: Record, 2000.

SCHILLING, Kurt, na sua História das idéias sociais. Rio de Janeiro: Zahar, 1966.

TOURAINE, Alain. O que é a democracia? Petrópolis: Vozes, 1995.

VALVERDE, José Maria et allii. História do pensamento. São Paulo: Nova Cultural, 1987. V. 1.

VIEIRA, Liszt. Cidadania e globalização. 2. ed. Rio de Janeiro: Record, 1997. 